\title{
Mentira frente a verdad en las disputas medievales entre católicos y heréticos
}

\author{
Emilio MitRe FERNÁNDEZ \\ Universidad Complutense de Madrid \\ mitrefernandez@gmail.com
}

\begin{abstract}
RESUMEN
Las polémicas entre mentira (importante vitium linguae según los moralistas) y verdad (identificada con una idea superior, incluso con la divinidad) han sido muy características de la Europa cristiana medieval. Sobre bases bíblicas, patrísticas, escolásticas y prerrenacentistas, las disputas han afectado tanto a los medios académicos (vg. la teoría de la Duplex veritas atribuida a los averroístas) como al común de los cristianos (vg. El recurso a la ordalía).
\end{abstract}

Palabras clave: Medievo, verdad y mentira, ortodoxia y herejía.

The Lie opposite to the Truth in the medieval controversies between Catholics and Heretics

\begin{abstract}
The controversies between the lie (important vitium linguae according to the moralists) and the truth (identifies with a superior idea and with the Divinity itself) have been very characteristic of the Christian medieval Europe. Supported by the biblical, patristic, scholastic and pre- Renaissance arguments, the quarrels have affected the academic environment (vg.: the theory of duplex veritas attributed to the averroist) and the totality of the Christian society (vg: the resource to the ordeal).
\end{abstract}

Keywords: Europe in Middle Ages, truth and lie, orthodoxy and heresy.

SUMARIO: 1 . Tradición escrituraria y protopatrística. 2 . Verdad y trascendencia en algunos pilares intelectuales del Medievo. 3. Mendacium, periurium y falsum testimonium contra verdad. 4. Las fluidas fronteras entre verdad y mentira en el mundo académico. 5. La verdad al albur de la ordalía. 6. Proyección social de la dialéctica verdad/mentira en el debate heresiológico. 7. Conclusiones. 
La mentira, un vitium linguae considerado extraordinariamente difundido ${ }^{1}$, contará en el Medievo con una amplia literatura reprobatoria. Sucederá tanto en el campo de la ortodoxia como en el de los movimientos heréticos, convencidos ambos de la rectitud de sus puntos de vista. Al igual que los vicios capitales tenían sus opuestas virtudes, a la mentira y taras afines, se oponía la verdad, de la que el pensamiento cristiano facilitó diversas visiones.

Junto a la(s) verdad(es) la teología insistió en un especial sentido de ésta, al asimilarla al corpus dogmático con el que todo fiel debía comulgar. En último término (en singular y habitualmente con mayúscula) Verdad es una suprema categoría que todo lo trasciende ${ }^{2}$. Estamos ante una referencia que se remite a menudo a la figura de Dios a quien se identifica con la Verdad misma. Aún siguiendo métodos y discursos diferentes, diversas figuras de la intelectualidad del Medievo llegarán a conclusiones muy similares.

\section{TRADICIÓN ESCRITURARIA Y PROTOPATRÍSTICA}

Teológicamente, verdad significa «revelación de Dios que culmina en Jesucristo y que se transmite hasta nuestros días». Los inicios del Antiguo Testamento dan ya pistas para fijar lo que, para el futuro, van a ser los contrapuestos conceptos de mentira y de verdad.

\section{a) La base veterotestamentaria y tardojudaica}

Desde sus comienzos la humanidad vio marcado su destino por un engaño: el de la serpiente que asegura a la mujer que ella y su compañero serán conocedores del bien y del mal desde el momento que coman del fruto prohibido (Gen 3. 2-5) ${ }^{3}$. Como contrapartida, la verdad aparece (derivación del hebreo emeth) como equivalente de firmeza, fidelidad, estabilidad, paz, seguridad o recta vía (Gen 24, 27). Acaba por convertirse en algo más que un concepto filosófico: será una derivación de la alianza puesto

\footnotetext{
${ }^{1}$ El vitium linguae en sus distintas manifestaciones se estimaba en la Edad Media como una especie de culminación de los siete vicios capitales. Sobre este tema vid. el interesante libro de C. Casagrande y S. Vecchio, Les pechés de la lange. Discipline et éthique de la parole dans la culture médiévale, Paris 2007. A completar con otra no menos interesante obra de estas dos autoras: I sette vizi capitali. Storia dei peccati nel Medioevo, Torino 2000. La profesora S. Vecchio tiene además un trabajo específico sobre la mentira y conceptos afines: «Mensonge, simulation, dissimulation. Primauté de l'intention et ambigüité du langage dans la théologie morale du bas Moyen Age » en Vestigia, imagines, verba: Semiotics and Logic in Medieval Theological Texts, XIIth-XIV century. Acts of the XI Simposium on Medieval Logic and Semantics (San Marino 24-28 may 1994) Eds.de J. Jolivet y C. Marmo, Turnhout, 1997, pp. 117-132.

${ }^{2} \mathrm{La}$ «verdad trascendental» es considerada como «el concepto fundamental de la verdad» por H. Rings, «Voz Verdad. I. Filosofía», en Conceptos fundamentales de la teología, Dir. H. Fries t. II Madrid, 1979, p. 855.

${ }^{3}$ Sobre el tema del pecado original pueden consultarse algunas obras cuya naturaleza oscila entre lo teológico y lo histórico: L. Ligier, Peché d'Adam, peché du monde. 2 vols, Paris, 1961; E. Elorduy, El pecado original. Estudio de su proyección histórica, Madrid, 1977; o G. Minois, Les origines du mal. Une histoire du peché originel, Paris, 2002.
} 
que Dios mantiene lo prometido y es el refugio del justo $(\mathrm{Sa}$. 91,4). La verdad del hombre en relación con Dios consiste en servir al Señor, quitando de en medio «los dioses a los que sirvieron vuestros padres en Mesopotamia, y en Egipto» (Jos 24, 14) ${ }^{4}$

En el judaísmo posterior, tomó cuerpo una idea: Dios mismo es la Verdad; un tema que daría extraordinario juego también en la teología cristiana ${ }^{5}$. En documentos de las comunidades del Mar Muerto se hacen solemnes invocaciones a su triunfo final tras un encarnizado combate escatológico: «Verdad y justicia resplandecerán en todos los confines del orbe, iluminando sin cansancio hasta que se hayan llenado los tiempos establecidos para las tinieblas» ${ }^{6}$. Se reprueba, asimismo, a quienes «enseñan torpemente y con mentira. Sus acciones serán reveladas al final del tiempo como malvadas, delante de todo Israel» ${ }^{7}$.

\section{b) Los aportes neotestamentarios}

Bajo el término aletheia (similar al hebreo emeth) se designará en el Nuevo Testamento la veracidad, la fidelidad y la rectitud ${ }^{8}$. Testimonios paulinos y joánicos serán decisivos a la hora de configurar esa idea en su más alto grado.

San Pablo, al referirse a la miseria moral de los paganos, dirá que «ellos han colocado la mentira en el lugar de la verdad de Dios, dando culto y sirviendo a las criaturas en lugar de adorar al Creador, el cual es bendito por todos los siglos» (Rom. $1,25)^{9}$. La predicación del Evangelio será «palabra de verdad» $($ Col. 1, 5) con lo que el mensaje de fe cristiana pasa a categoría de verdad absoluta. Abundaría asimismo en la identificación entre verdad y comportamiento a seguir por el cristiano diciendo: «No mintáis los unos a los otros; desnudaos del hombre viejo con sus acciones» (Col. 3, 9).

Uno de los pasajes paulinos más citados desde la heresiología ha sido el famoso «Oportet haereses esse» (1 Cor 11,19) traducible como «Es necesario que entre vosotros haya herejías», entendiendo por tal la variedad de opiniones; o la existencia de

\footnotetext{
${ }^{4}$ R. Fisichella, Voz «Verdad», en Diccionario teológico enciclopédico, Estella, 1999, pp. 117-118.

${ }^{5}$ En la tradición del De Trinitate de San Agustín, pieza clave del pensamiento teológico occidental, Severino Boecio (c. 480-525) defenderá una sustancia única para las tres personas, así como también una verdad única para Padre, Hijo y Espíritu Santo. Boèce, «Le Père, le Fils et le Saint.Esprit, sont-ils des attributs substantiels de la divinité (Utrum Pater)», en Courts traités de Théologie (Opuscula sacra) Ed-de H. Merle, Paris, 1991, pp. 117-118. En nuestros días, la autoridad papal ha vuelto a insistir en estas cuestiones recordando que el Dios bíblico es a la vez «Ágape y Logos: Caridad y Verdad. Amor y Palabra» Benedicto XVI, «Carta encíclica Caritas in Veritate». Recogida en Alfa y Omega. Semanario católico de información num. 649 /9-72009 p. 7. Su predecesor, Juan Pablo II, hizo también otra importante invocación a la verdad al referirse a algunas cuestiones fundamentales de la enseñanza moral de la Iglesia: Veritatis splendor, de 6 de agosto de 199.

${ }^{6}$ «Manual de la guerra de los hijos de la luz contra los hijos de las tinieblas», en Los documentos de Qumran. Ed. de M. Jiménez y F. Bonhomme, Madrid, 1976, p. 142.

7 «Comentario a Nahún», en ibid. p. 189.

8 J. Gnilka, voz «Verdad. II Sagrada Escritura», en Conceptos fundamentales de la teología, t. II, p. 865.

${ }^{9}$ Destacado por J. H. Fitzmayer, Teología de San Pablo, Madrid, 1975, p. 82. A propósito de esta misma epístola, el conocido teólogo calvinista O. Cullmann recordó que fue el arma de San Agustín contra los pelagianos y también que «los reformadores Lutero y Calvino hicieron de ella el baluarte de la verdad». El Nuevo Testamento, Madrid, 1971, p. 98.
} 
bandos ${ }^{10}$. Algo que resultaría extraordinariamente llamativo, escandaloso incluso, si prescindiéramos de la segunda parte de la sentencia: «...para que se manifiesten entre vosotros quienes son de probada virtud». La herejía/bando adquiere así un gran valor instrumental en tanto, sensu contrario, permite resaltar las verdades de fe (manifestaciones parciales de la Verdad en su más alto sentido) merced a los méritos y la capacidad intelectual de sus expositores ${ }^{11}$.

La respuesta de Jesús a la pregunta de Tomás «¿cómo podemos saber el camino?... Yo soy el Camino, la Verdad y la Vida; nadie viene al Padre sino por mi» constituirá un mensaje neotestamentario clave (Jn 14, 5,6). Otros pasajes de los textos del apóstol y evangelista Juan resultan también ilustrativos: «Decía (Jesús) a los judíos que creían en él: si perseveráis en mi doctrina, seréis verdaderamente discípulos míos. Y conoceréis la verdad, y la verdad os hará libres» (Jn 8, 31-32). En contraposición, el diablo aparece como «mentiroso y padre de la mentira» $(\mathrm{Jn} 8,44)^{12}$. Jesús se presenta ante Pilatos como quien ha venido «a dar testimonio de la verdad: todo aquel que pertenece a la verdad, oye mi voz». A lo que el procurador de Judea replica con una pregunta entre escéptica y generalizadora: «¿Qué es la verdad?» (Jn 18, 37-38 ). Asimismo se contrapondrá la mera palabra sin apoyo con las obras y la verdad: «Hijitos míos, no amemos de palabra y con la lengua, sino con obras y de veras. En éstos echaremos de ver que somos de la verdad, y alentaremos nuestros corazones en la presencia de Dios» (1 Jn 3, 18-19). Tras su marcha de este mundo Jesús promete el Paráclito, el Espíritu de la Verdad (Jn 15, 26). La inserción de la verdad en la historia hace de la presencia del Espíritu de Cristo resucitado el elemento que conduce a su Iglesia hasta la Verdad completa (Jn 16, 14). ${ }^{13}$

El Apocalipsis joánico, que cierra el canon bíblico, condenará a los embusteros (junto a cobardes, homicidas, deshonestos, hechiceros e incrédulos) al «lago que arde con fuego y azufre, que es la muerte segunda» (Ap 21,9). Una circunstancia que implica una transfiguración y glorificación que abarcará a la entera creación de Dios ${ }^{14}$.

\section{c) Albores de la patrística}

La primera patrística seguirá profundizando en estas ideas oponiendo la Verdad a la tergiversadora Mentira, consideradas ambas en su dimensión suprema ${ }^{15}$. Cabe remitirse a algunos ejemplos.

\footnotetext{
${ }^{10}$ Para la evolución de la exégesis de este pasaje, vid. H. Grundmann, «Oportet et haereses esse. Il problema dell'eresia rispecchiato nell'esegesi biblica medievale», en L'eresia medievale. Ed. de O . Capitani, Bologna, 1971, pp. 23ss.

${ }^{11}$ E. Mitre, Ortodoxia y herejía entre la Antigüedad y el Medievo, Madrid 2003, pp. 31-34. Sobre la idea de herejía en los primeros tiempos cristianos vid. la sólida monografía de A. Le Boulluec, La notion d'hérésie dans la littérature grecque, II-III siècles, Paris, 1985.

${ }^{12}$ Citado recientemente por F. Cardini quien recuerda la paráfrasis que hace Dante de ese pasaje joánico en «Infierno», cant. XXIII, en boca de Catalano de Malavolti . «Presentazione» a La menzogna (Coord. De F. Cardini). Firenze, 1989, pp. 10-11.

${ }^{13}$ P. Ricoeur, Historia y verdad, Madrid, 1990.

${ }^{14}$ E. Schick, El Apocalipsis, Barcelona, 1979, p. 274.

${ }^{15}$ La herejía pasa a ser una perversión identificada con la mentira E. Mitre, Ortodoxia y herejía pp. 43ss.
} 
San Ignacio de Antioquía, (¿discípulo de San Juan?), hablará de la necesidad de taparse los oídos «cuando alguno os hable excluyendo de Jesucristo estas verdades»; y se remite para ello a ciertos elementos del símbolo de fe cuestionados por los herejes docetistas: la genealogía davídica de Cristo, su nacimiento de María, su crucifixión y resurrección ${ }^{16}$.

Unos años más tarde, Ireneo de Lyon (c. 130- c. 200) estableció en su Adversus omnes Haereses lo que será la visión canónica de una secuencia cronológica: la antigüedad de la verdad (la ortodoxia) se oponía a la novedad del error (las herejías). ${ }^{17}$

A principios del siglo III, Tertuliano se manifestaría ardientemente contra los que denomina espíritus del error que adulteran la doctrina verdadera: «Decididamente oponemos a los que nos adulteran (con una serie de fábulas que pretenden debilitarla) esta afirmación fundamental: la regla de la verdad (que) es la que proviene de Cristo transmitida por sus discípulos» ${ }^{18}$. Y, a mediados de la centuria, Cipriano de Cartago previene de los «que engañan con sutileza y astucia» inventando herejías y cismas para «tergiversar la fe, corromper la verdad y romper la unidad». Esos mismos, reitera mas adelante, «se separan de nosotros y abandonaron la fuente y el origen de la verdad cuando, constituyéndose por su cuenta en diversos grupitos, surgieron la herejía y el cisma» ${ }^{19}$.

Durante los primeros tiempos de la Iglesia asistimos a una reprobación de las mentiras de los herejes y una consiguiente defensa de la Verdad desde posiciones que tienen mucho de puramente personal. Con los primeros concilios reconocidos como ecuménicos se publicitará solemnemente esa Verdad imponiéndosela al conjunto de la sociedad cristiana ${ }^{20}$.

En uno de los textos previos a la celebración del concilio de Nicea (325) se dirá que los arrianos «se han aplicado a mezclar la mentira con la verdad, la impiedad con la ortodoxia. Pero no saldrán con la suya. Porque vencerá la verdad, y no hay nada común entre la luz y las tinieblas, ni acuerdo entre Cristo y Belial» ${ }^{21}$. Unos años más

\footnotetext{
16 «Cartas de San Ignacio. Carta a los tralianos», en Textos cristianos primitivos. Ed. de T. H. Martín, Salamanca, 1991, p. 99.

${ }^{17}$ Esquema cuestionado con el discurrir de los años. W. Bauer, en Rechtgläubigkeit und Keitzerei im ältesten Christentum, Tubinga, 1964 (ed. or. 1934) sostenía que las manifestaciones heréticas (diversidad de puntos de vista, de acuerdo con el sentido más etimológico de la expresión) serían las que configurarían el primitivo cristianismo. Solamente con el tiempo la ortodoxia (la verdad, en el sentido más clásico) acabaría imponiéndose a través de las grandes proclamaciones doctrinales. En ese proceso los primeros concilios ecuménicos habrían desempeñado un papel capital. H. E. Turner en The Pattern of the Christian Thought, London, 1954, mantenía en una línea más ecléctica, que en el cristianismo coexistieron ciertos elementos fijos junto a otros más flexibles, provenientes estos últimos de la terminología y de los conceptos filosóficos empleados. Vid. M. Simon y A. Benoit, El judaísmo y el cristianismo antiguo. De Antíoco Epífanes a Constantino. Barcelona, 1972 pp. $219-231$

18 Tertuliano, El apologético. Ed. de J. Andino, Madrid, 1997, p. 174.

${ }^{19}$ Cipriano. La unidad de la Iglesia. Ed. de C. Failla y J. Pascual, Madrid, 1991. pp. 72 y 85.

${ }^{20}$ Lo que he designado en otra parte como «escenificación de la ortodoxia en la Iglesia universal» E. Mitre, Ortodoxia y herejía, pp. $117 \mathrm{ss}$.

${ }^{21}$ «Carta de Alejandro de Alejandría a los obispos», en I. Ortiz de Urbina, Nicea y Constantinopla. (tomo I de Historia de los Concilios Ecuménicos) Vitoria, 1969, p. 252.
} 
tarde (362) se presentará, asimismo, a los herejes arrianos y sabelianos como «ajenos a la verdad»... y a los maniqueos como inventores de maldades ${ }^{22}$. Y en el Edicto de Tesalónica promulgado por el emperador Teodosio previamente a la celebración del I Concilio de Constantinopla, se designan como «maliciosas astucias» las maniobras de los arrianos para la adquisición de iglesias y su defensa de propuestas de fe distintas a las establecidas en $\mathrm{Nice}^{23}$. En definitiva, a lo largo del siglo IV fue tomando cuerpo no solo el proceso de oficialización del cristianismo sino también el de identificación de ortodoxia y verdad.

\section{VERDAD Y TRASCENDENCIA EN ALGUNOS PILARES INTELECTUALES DEL MEDIEVO}

Será San Agustín, «gran discípulo de la Verdad» ${ }^{24}$, quien presente a ésta como Principio, Verbo de Dios en Dios, Luz de Dios... ${ }^{25}$. Siglos más tarde, y en una línea también agustiniana, San Anselmo escribiría una obrita bajo el título De Veritate; en ella aparecía Dios como la verdad suprema, que causa y mide todas las cosas. Él es causa de todas las otras verdades: de la verdad de los pensamientos y de las proposiciones. Es la Verdad subsistente ${ }^{26}$. Todos los caminos del Señor, reitera San Anselmo en otro breve tratado, son «misericordia y verdad» $(\mathrm{Sal} 24,10)^{27}$

Se ha jugado con la influencia de San Anselmo en Santo Tomás ${ }^{28}$, la gran referencia intelectual de la cultura católica, quien dedicó al tema de la verdad importantes páginas de sus Questiones disputatae, una figura propia de la epistemología y metodología medievales ${ }^{29}$. Diría que «la verdad en sentido propio y primario, está en

22 «Tomo a los antioquenos de Atanasio», en ibid. p. 274.

${ }^{23}$ Codex Theodosianus, lib. XVI, I, 2-3. Recogido en la antología de E. Mitre, Iglesia y vida religiosa en la Edad Media, Madrid, 1991. pp. 65-66. Sobre Teodosio I vid. las recientes biografías de P. Maravall, Théodose le Grand. Le pouvoir et la foi, París, 2009. y G. Bravo, Teodosio. Último emperador de Roma, primer emperador católico, Madrid, 2010.

${ }^{24}$ Tal y como lo presenta Pedro Abelardo, Diálogo entre un filósofo, un judio y un cristiano. Ed de A. Sanjuán y M. Pujadas, Zaragoza, 1988, p. 222.

${ }^{25}$ San Agustin, De vera religione, cap. XXXVI. Vid. algunas reflexiones al respecto en «El saber agustiniano», estudio introductorio de A. Martínez a Ideario de San Agustín, Madrid, 1957, p. 40. Tambien, B. Studer, «Cristo-verdad en el pensamiento trinitario de Agustín de Hipona», en Estudios trinitarios, 41 (2007) pp. 7-39.

${ }^{26}$ San Anselmo, De Veritate. 13. Patrología Latina vol. 158 col. 486. En A. Maurer, Filosofía medieval, Buenos Aires 1967, p. 54-56 se recuerda que esta idea de la Verdad, conectaría con el anselmiano argumento «ontológico» de la existencia de Dios.

${ }^{27}$ San Anselmo, Proslogion. c. 11. Ed. de J. Rivas y J. Corominas, Madrid, 1998, p. 27.

${ }^{28}$ F. Rego, «La doctrina de la verdad según San Anselmo: su posible proyección sobre Santo Tomás de Aquino», en Metafísica y dialéctica en los período carolingio y franco (ss. IX-XI). II Jornadas de pensamiento medieval, ed. de J. Cruz Cruz y M. J. Soto-Bruna, Pamplona 2006, pp. 217-234.

${ }^{29}$ Vid. dos ediciones de este texto Santo Tomás de Aquino, De veritate Ed. de H. Giannini y O. Velásquez, Santiago de Chile, 1996 y Tomas de Aquino, Sobre la verdad, Cuestiones disputadas sobre la verdad, Ed. de J. Valverde. Clásicos del Pensamiento. Biblioteca Nueva. Madrid, 2003.(por esta versión citaremos en adelante) También J. García López, Doctrina de Santo Tomás sobre la verdad, Pamplona, 1967 ; C. González-Ayesta, La verdad como bien según Santo Tomás de Aquino, Pamploa, 2006 y W. Senner, «La verdad en Alberto Magno y en Tomás de Aquino» en Anámnesis, 19 (2009) pp. 75-127. 
el entendimiento divino; en el entendimiento humano, en cambio, lo está en sentido propio y secundario... La verdad conforme a la que el alma juzga acerca de todas las cosas es la verdad primera» ${ }^{30}$. Al referirse en otro texto (el Compendium theologiae) a la unidad, inmutabilidad, eternidad, etc como cualidades de Dios, sostendría que «aquellos que expusieron la verdad no han podido conocerla sino después de largas y laboriosas investigaciones». La comprensión de tales nociones solamente había estado al alcance de la doctrina cristiana; los filósofos paganos no habían podido acceder a ellas ${ }^{31}$. En línea con lo defendido por San Agustín, - «la felicidad es el gozo de la verdad (gaudium de veritate), es decir, el gozo de ti que eres la Verdad, oh Dios, mi luz» ${ }^{32}$ - el Aquinate dirá que «la alegría considerada en sí misma es la consumación de la beatitud» ${ }^{33}$.

Una generación posterior y también en la tradición anselmiana Juan Duns Scoto, el doctor sutil, invocará a Dios en su visión de «la simplicidad, la infinitud y la intelectualidad del primer ente» diciendo: «Sólo Tu eres la Verdad Primera; pues todo lo que no es como aparece, es falso» ${ }^{34}$. Jugando con conceptos otra vez agustinianos, el maestro Eckhart llegará a unas conclusiones similares años más tarde al glosar el pasaje evangélico de la expulsión de los mercaderes del templo: «Luz y tinieblas no pueden subsistir juntas. Dios es la Verdad; no es en sí mismo más que la luz» ${ }^{35}$. Y en uno de los textos capitales de la espiritualidad cristiana redactado a fines del Medievo -el atribuido a Tomas Kempis- se insistirá en que «Dios es la verdad. Bienaventurado aquel a quien la verdad por sí misma enseña, no por figuras y voces que se pasan, sino así como es» ${ }^{36}$.

\section{MENDACIUM, PERIURIUM Y FALSUM TESTIMONIUM CONTRA VERDAD}

Mentira, perjuicio y falso testimonio serán golpes que se producirán desde tiempo inmemorial ${ }^{37}$. El Medievo los situará entre las perversiones más comunes de los herejes; a través de ellos se contaminaba la doctrina y se sorprendía a las personas más desarmadas intelectualmente.

\footnotetext{
30 Tomás de Aquino, Sobre la verdad, C. 1, art. 4. ed. cit. pp. 80-82.

31 Tomás de Aquino, Compendio de teología (cap. XXXVI). Ed. de F. J. Fortuny y L. Carbonero, Barcelona, 1986, p. 36.

${ }^{32}$ San Agustín, Confesiones. Lib. X, 23. Ed. de J. Cosgaya, Madrid 2000, p. 340.

33 Santo Tomás en Suma Teológica I, II qu. 3. art 4. Concl, cf en Quaest. Quodlibetales. Qu. 9, art. 19. p. 72. Recogido en la antología de E. Gilson, Santo Tomas de Aquino, Madrid, 1949, p. 72.

${ }^{34}$ Duns Scoto, Tratado del primer principio. Ed. de A. Casado Piñán, Madrid, 1985, p. 150.

35 Oeuvres de Maître Eckhart. Sermons-traités. Ed de P. Petit y J-P. Lombard. París, 1987, p. 263. Y de la Segunda Persona de la Trinidad dirá que «El mismo es en la luz de este poder, el Hijo y la Verdad», ibid. p. 272.

${ }^{36}$ Imitación de Cristo. Lib. I cap. III Ed. P. Eusebio Nieremberg, Barcelona, 1947, p. 19.

37 Así, el octavo mandamiento del Decálogo imponía: «No levantarás falso testimonio contra tu prójimo» (Ex. 20, 16). Y en Lev. 19, 11 se ordena «No hurtarás. No mentirás. Ninguno engañará a su prójimo». Lo que, en un sentido mas pragmático suele definirse como «no levantar falsos testimonios ni mentir».
} 


\section{a) La tradición patrística y su seguimiento}

San Agustín ${ }^{38}$ redactó dos textos específicos contra la mentira que ejercieron una notable influencia en las generaciones posteriores. El primero, bajo el título De mendacio, lo escribió en torno a 395: con alcance muy general, fija hasta ocho categorías de mentiras, la primera de las cuales es la más grave de todas: «La mentira capital y la primera que hay que evitar decididamente es la mentira en la doctrina religiosa ${ }^{39}$. Dejaría así sentadas las bases para redactar, hacia 420, otro opúsculo bajo el título Contra mendacium. Orientado a rebatir a los priscilianistas, considerados mentirosos por principio, dice que «se han atrevido a dogmatizar la mentira para ocultar lo que ellos dicen que es verdad» ${ }^{40}$. Advierte asimismo a los católicos para que no utilicen frente a estos herejes esa misma arma.

En abierto desafío a la mentira, Benito de Nursia recomendará a sus monjes entre las buenas obras, «decir verdad con el corazón y con la boca» ${ }^{41}$.

Refiriéndose a las fuentes de la verdad, Casiodoro dirá que las Escrituras divinas «describen sin falsedad lo pasado, muestran lo presente más de lo que de él es visible, narran los hechos futuros como si ya se hubiesen cumplido... La verdad celestial se nos anuncia por medio de parábolas y misterios, de acuerdo con el alcance de nuestra inteligencia» ${ }^{42}$.

Hacia el 800 Beato de Liébana dirá que los herejes son «seductores (que) abandonan la verdad y son autores de la maligna mentira. Porfían en decir que son buenos y se comprueba que son peores que los demonios. Pero sus mentiras y su perversidad las descubrió la fe católica, y por tolerancia soportó los innumerables males que le infligieron $»^{43}$. Lamenta a la postre: «la sutileza herética que horada sutilmente las almas con los aguijones de las palabras y nos rodea con tanta astucia, (es tal) que el engañado ni ve ni entiende en qué ha sido engañado» ${ }^{44}$.

Bajo la inspiración agustiniana se moverán Gregorio Magno y, más adelante, autores de la Edad Media clásica como Raul Ardent o Alain de Lille para quien el vicio

${ }^{38}$ M. Mindán, «La verdad, ideal supremo en San Agustín», en Revista de filosofía, 14 (1955) pp. 3-22 o M. A. Sánchez Manzano, «La expresión de la falsedad y del error en el vocabulario agustiniano de la mentira», en Augustinus, 34 (1989) pp. 267-280.

${ }^{39}$ San Agustín, «Sobre la mentira», en Tratados morales, (t. XII de Obras de San Agustín, en vol. 121 de B.A.C) Madrid, 1954, p. 577. «La verdad de la doctrina, de la religión y de la piedad no se viola más que con la mentira» sentencia. Ibid, p. 599.

${ }^{40}$ San Agustín, «Contra la mentira» en Tratados morales. p. 617. Hay que recordar que por mendacidad se entiende, técnicamente, algo más que la mentira: es el hábito de mentir, con lo que constituye un vicio más que un pecado en el sentido puntual del término. Cf. La distinción de Santo Tomás entre el habitus que caracteriza tanto al vicio como a la virtud y el acto -desordenado- que (por principio voluntario) es lo que define al pecado. Suma teologica I, II qu. 72, art 2 concl. Recogido en E. Gilson, Santo Tomás de Aquino, pp. 269ss.

${ }^{41}$ Regla del gran patriarca San Benito. C. IV. 28. Abadía de Sto Domingo de Silos, 1993, p. 34.

${ }^{42}$ Casiodoro, Iniciación a las Sagradas Escrituras. Ed. de P. B. Santiago, Madrid, 1998, p. 153.

${ }^{43}$ Beato de Liébana, «Comentario al Apocalipsis de San Juan» en Obras completas de Beato de Liébana. Ed. de J. González Echegaray, A. del Campo y L. G. Freeman. Madrid, 1995. p. 183.

${ }^{44}$ Ibid. 203. En su «Apologético», el mismo Beato volverá a insistir en la agudeza de los predicadores heréticos que ocultan su predicación bajo argumentos falaces. En Ibid. p. 945. 
de la mendacidad engendra la herejía ${ }^{45}$. El privilegio que se suele otorgar a la palabra único que, en cierta medida permite acceder a la divinidad, explica la atención que dio Ramón Llull a la culpabilidad de la palabra - especie de sexto sentido- cuando se expresa a través de la mentira ${ }^{46}$.

b) La producción catequética y su influencia: el ejemplo hispánico

En la línea agustiniana, que parece inevitable en todos los campos, se mantuvo la producción pastoral. Tendrá una buena manifestación en el catecismo del obispo de Segovia Pedro de Cuellar (1325) el primero de este género de carácter amplio redactado en castellano. A propósito del «non dirás falso testimonio» dice que «falsedad es mandamiento de verdat fecha de çierta ciencia con engaño» ${ }^{47}$. Siguiendo al padre norteafricano, los diversos tipos de mentira pueden agruparse en tres categorías: la que perjudica al prójimo, la que redunda en descrédito de Dios o de la fe, o la que proporciona beneficios a quien la dice. La envergadura de una mentira -no todas son igualmente graves-se mide por el efecto provocado: mentir por divertir a los que escuchan es pecado venial; es pecado mortal cuando se causa daño al prójimo («por traerle a muerte o enpeçerle de otra manera») o cuando se hace un daño de naturaleza espiritual «que sea tirada de la fe católica o de reglas de buenas costumbres» como que Cristo no se ha encarnado o diga que la lujuria no es pecado morta ${ }^{48}$. Algunas de estas situaciones estaban incursas en el crimen de herejía cuando negaban alguno de los artículos de fe.

Con más parquedad se expresa el coetáneo catecismo del cardenal Gil de Albornoz que se limita a decir que: «Octavum est "non loqueraris contra proximum tuum falsum testimonium' per quod etiam ut habetur in glossa prohibetur omne mendacium $»^{49}$; o el del obispo de Pamplona Arnaldo de Barbazán quien dirá que «el octavo mandamiento es no dirás falso testimonio contra tu prójimo» ${ }^{50}$.

El canciller y cronista Pero López de Ayala, testigo privilegiado de los avatares de la segunda mitad del XIV, nos legó en su Libro rimado del Palaçio un texto de importancia capital en diversos campos. Atinadamente alguien lo ha definido como una especie de testamento moral del autor ${ }^{51}$. Es también una suerte de examen de con-

${ }^{45}$ C. Casagrande y S. Vecchio, Les pechés de la langue pp. 33 y 200. También M. Vincent-Cassy, «Recherche sur le mensonge au Moyen Âge», en 102 Congrés National des societés savantes. Limoges, 1977 philol et hist. II pp. $165 \mathrm{ss}$.

${ }^{46}$ R. Llull, Liber de virtutibus et peccatis sive Ars major praedicationis. Ed. de F. Domínguez Reboiras y A. Soria Flores. CCM. 76, Turnhout, 1987, p. 159ss. Recogido por C. Casagrande y S. Vecchio, Les pechés de la langue, p. 163.

${ }^{47}$ Religión y sociedad medieval. El catecismo de Pedro de Cuellar (1325).Estudio y edición de J. L. Martín y A. Linaje Conde, Salamanca, 1987, p. 182.

48 Ibid. p. 119 s y 182 s.

49 «El catecismo de Albornoz» en Studia Albornotiana (Ed. y comentario de Derek. W. Lomax) vol. XI. Publicaciones del Real Colegio de España, 1972, p. 230.

50 «El catecismo de Arnaldo de Barbazán, obispo de la Diócesis de Pamplona (1318-1355)», (Ed. y comentario de E. García Fernández) en En la España Medieval num. 15 (1992) p. 331.

${ }^{51}$ G. Orduna, «El Rimado de Palacio, testamento político-moral y religioso del Canciller Ayala» en Estudios homenaje a D. Claudio Sánchez Albornoz en su 90 aniversario. Anejos de Cuadernos de Historia de España, (1986), pp. 215ss. 
ciencia de un hombre que se sabe pecador cuando, revisando el Decálogo, se hace cargo de las muchas ocasiones en que ha caído en falta. Al encontrarse con el Octavo mandamiento pide clemencia a la divinidad por las veces que ha faltado contra la fama de otros al levantar falsos testimonios. Un hecho especialmente grave ${ }^{52}$ tratándose del mundo de los caballeros a los que se consideraba poseedores de un especial código ético: «De bivos e de muertos, Señor, yo profaçé (difamé) / afirmé muchas vezes cosas que non las sé / enfamé al cristiano e su fama dañé: / por que, Señor, te pido perdón pues que erré» ${ }^{53}$.

\section{c) La verdad y la palabra dada}

El amor a la verdad es una cualidad del cristiano, tanto más apreciada cuanto su nivel de responsabilidades es más alto: el de los nobles y eclesiásticos y, sobre todo, el de los gobernantes. Los textos legales del Medievo referidos a los monarcas corren parejos a un género - los espejos de príncipes- que abunda en las cualidades morales que se consideran más idóneas para el buen ejercicio de sus funciones. Alfonso $\mathrm{X}$ en su más conocida compilación legal reprende a los reyes que pronuncian por su boca «palabras menguadas»: los Reyes «que tienen su logar en la tierra aquien pertenece de la guardar mucho, deuen parar mientes, que non sean contra ella, diziendo palabras mintrosas $\rangle^{54}$.

En bastantes ocasiones la verdad se confundirá con la guarda estricta de la palabra dada, con lo que entraríamos en las fronteras entre dos significados: el de verdad y el de veracidad, definida esta última como «la virtud por la que nos afanamos en cumplir nuestras promesas con quienes las contrajimos $»^{55}$. Del rey de Francia Luís IX, modelo de caballero cristiano y de prud'homme ${ }^{56}$, su biohagiógrafo Jean de Joinville dirá: «El santo rey amó tanto la verdad que, incluso se negó a incumplir acuerdos que había suscrito con los sarracenos», pese a las insinuaciones que algunos de sus consejeros le hicieron ${ }^{57}$.

${ }^{52}$ Se ha destacado el contraste entre el pensamiento eclesiástico, poco dado a este tipo de exaltaciones, y la tradición creada por la lírica provenzal y la épica romance mucho mas propicias Vid. el tratamiento erudito y muy inventarial de este tema en M. R. Lida de Malkiel, La idea de la fama en la Edad Media castellana. México ,1983 (reimpresión de la edición de 1952) especialmente pp. 116, 126, 136. y 159.

${ }^{53}$ Pero López de Ayala, Libro rimado del Palaçio. Ed. de J. Joset. T. I, Madrid, 1978, p. 81s. En la monografía citada no hay ninguna mención al cronista canciller a propósito de la exaltación de la fama y la gloria, cuando sí se tratan prolijamente otros autores cercanos como Juan de Mena, el autor de El Victorial o Fernán Pérez de Guzmán.

${ }^{54}$ Las siete partidas (glosadas por el licenciado Gregorio López). Segunda Partida tit IIII ley III, Salamanca 1555 t. I, fol. 11.

${ }^{55}$ Pedro Abelardo, Diálogo entre un filósofo, un judio y un cristiano, p. 175.

${ }^{56}$ La prudhomía resulta una cualidad nada fácil de definir. Implicaba el ejercicio prudente y moderado del poder, la utilización de un lenguaje mesurado, la frugalidad en la mesa o la huida de la impureza y la mentira Vid. la innovadora biografía de J. Le Goff, Saint Louis, Paris, 1996. Una semblanza de este monarca y de las cualidades que le rodearon en E. Mitre, «Realeza del Medievo y santidad ministerial: el modelo de Luís IX de Francia», en XX siglos, 56 (2006) pp. 33-42.

${ }^{57}$ Refiriéndose al pago del rescate al que el monarca se había comprometido tras su prisión en Egipto. Joinville, Vie de Saint Louis. Ed. de J. Monfrin, Paris, 1995, p. 11, cf p. 191 y p. 377. 
d) La especial lógica de las guías inquisitoriales

El perfeccionamiento del aparato represivo, tal y como se hará de forma especial desde los inicios del siglo XIII con el papa Inocencio III, implicará la institucionalización de la inquisición pontificia a la que se dotará de los instrumentos necesarios para el ejercicio de sus funciones. Entre ellos, la redacción de manuales que, en ciertos casos, adquirirán alguna popularidad. Según las indicaciones que recogen, uno de los defectos más comunes de los herejes era el de ocultar sus errores en vez de confesarlos francamente.

El inquisidor Bernard Gui (hacia 1321-1322) hablaba del gran embarazo que se producía entre sus colegas al ejercer sus funciones. Bien porque su conciencia se atormentara al castigar sin suficiente convicción de la existencia de herejía; bien por quedar atrapado en una maraña de falsedades, engaños y malicias del acusado ${ }^{58}$. Los herejes especialmente estudiados por este autor (cátaros, valdenses, apostólicos y beguinas) son acusados de duplicidad y falsedad ${ }^{59}$; de duplicidad y engaño en sus palabras $^{60}$; de «alterar la verdad, negarla y paliarla por todos los subterfugios posibles» ${ }^{61}$; o de ambigüedad y oscuridad en sus respuestas ${ }^{62}$.

En el manual de inquisidores de Nicolau Eimeric (redactado en la segunda mitad del XIV y profusamente anotado dos siglos después por Francisco Peña) la mentira se encontrará en el mismo saco que las herejías: «herejías, otros errores, otras temeridades, otras falsedades y dudosas afirmaciones sobre la fe» se dice ${ }^{63}$. El «hereje es el que diga cosas contrarias a las verdades esenciales de la fe». Los otros alejamientos de la verdad serán: las sospechas fundadas de islamización, la incomparecencia a la llamada del inquisidor, el incumplimiento de una pena canónica impuesta por el inquisidor, la petición del consolamentum en el momento de morir al estilo de los cátaros, o la recaída en la herejía, el trato con herejes, el incumplimiento del precepto dominical o de la práctica sacramental, entre otros ${ }^{64}$.

${ }^{58}$ Bernard Gui, Manuel de l'inquisiteur. Ed. de G. Mollat, Paris, 1926 (reimpresión de 2006), p. 7.

${ }^{59}$ Especialmente a los cátaros, ibid. p. 17.

${ }^{60}$ Caso de los valdenses, Ibid. p. 65.

${ }^{61}$ Caso de los apostólicos, Ibid. p. 93.

${ }^{62}$ Refiriéndose a beguinos y beguinas, Ibid. p. 189.

${ }^{63}$ Vid. a título de ejemplo, «Sentencia condenatoria de las obras y errores de Arnaldo de Vilanova» (8 de noviembre de 1316) recogida en Escritos condenados por la inquisición de Arnaldo de Vilanova. Ed. de E. Cánovas y F. Piñero, Madrid, 1976, p. 55.

${ }^{64}$ N. Eimeric y F. Peña, El manual de los inquisidores. Ed. de L. Sala-Molins Barcelona, 1983 p. 157s. Con el discurrir de los años, y como contrapartida, valdría recordar al publicista judeo-húngaro en lengua alemana Max Nordau autor de una obra bajo el título Conventionelle Lügen der Kulturmenschheit publicada en 1883. Las «mentiras convencionales» eran las prácticas religiosas y los principios dogmáticos en contraste con la experiencia. También la adhesión a formas políticas carentes de sentido, o las instituciones económicas y morales, incluso la familia tal y como la constituían la Iglesia o el Estado. Frente a todo ello abogaba por una moral natural de solidaridad humana. Cf. M. Venturini, Voz «Las mentiras convencionales de nuestra civilización», en Diccionario literario de obras y personajes de todos los tiempos y todos los países. T. VII, Barcelona 1967, p. 98. 


\section{LAS FLUIDAS FRONTERAS ENTRE VERDAD Y MENTIRA EN EL MUNDO ACADÉMICO}

De manera contrita, San Agustín se lamentaba de haber estado durante su atormentada juventud buscando la verdad que era el Señor «que lo preside todo y yo, en mi avaricia, no quise perderte, pero quise poseerte junto con la mentira... Por eso te perdí, porque no aceptas que te posean a medias con la mentira ${ }^{65}$. Una reflexión que puede resultar útil para entrar en un campo muy especial.

a) ¿Una relativización de la verdad?

Diversas tomas de postura a propósito del valor y alcance de la verdad volverán a presentar a los herejes como servidores de la mentira.

San Agustín en un opúsculo catequético, advierte de la necesidad de guiarse «por los escritos de los más doctos varones que se distinguieron por la verdad». Existen, sin embargo dos riesgos: bien el seguir obras de algún hereje, «quizás ignorando que su lectura la reprueba la verdadera fe»; o bien hacer una mala interpretación de los escritos de autores indudablemente católicos que pueda presentarlos como «alejados de la verdad». Circunstancia que induce a «elaborar e inventar alguna herejía» ${ }^{66}$.

En consecuencia: «Que el pensamiento no se aparte de la verdad» y si «la vehemencia de la debilidad humana se hubiese también apartado de la misma verdad... debemos pensar que Dios quiso probar si somos capaces de corregirnos con placidez de ánimo, sin precipitarnos en otro error mayor para sostener nuestra equivocación» ${ }^{67}$.

Sobre los priscilianistas dirá que defienden una teoría que pudiéramos llamar la «doble mentira»: sostenían que no era grave mentir con la boca mientras se mantuviera la verdad en el corazón. Con ello, contraatacaba el padre norteafricano, los herejes estaban deshonrando a los mártires ya que, con esa lógica, debían haber mentido de palabra a fin de no inducir a sus perseguidores a convertirse en homicidas ${ }^{68}$. Llevado ello a su extremo, San Agustín atribuiría a los priscilianistas, dentro de su inquebrantable espíritu mentiroso, un primer mandato: «Jura, abjura, pero nunca confieses un secreto»» ${ }^{69}$.

Isidoro de Sevilla dirá que los herejes «aprenden sus mentiras con mucho estudio y con vehemente trabajo, luchan por no venir a la unidad de la Iglesia...» fundando para ello sociedades privadas ${ }^{70}$.

A causa de relativizar la verdad quedaron a lo largo del Medievo fuera de la ortodoxia destacados personajes e importantes corrientes de opinión.

\footnotetext{
${ }^{65}$ San Agustín: Confesiones. Ed. de J. Cosgaya, Madrid, 2000, lib. X, 41 p. 371.

66 San Agustín, Tratado catequístico. Ed. de A. Seage, Sevilla, 1991, p. 29.

${ }^{67}$ Ibid. p. 35.

${ }^{68}$ San Agustín, «Contra la mentira», en Tratados morales. pp. 617-619.

${ }^{69}$ Recogido en H. Chadwick, Prisciliano de Ávila, Madrid, 1978, p. 272.

${ }^{70}$ San Isidoro de Sevilla, Libro de las sentencias lib. 1 cap. 16, 148. Ed. de M. Andreu y J. Oteo, Sevilla, 1990, p. 101.
} 
En lugar preferente figuraría Pedro Abelardo a causa de ese subjetivismo moral deducible de su ética ${ }^{71}$ : la moralidad de un acto depende únicamente de la intención con la que se ha realizado. El pecado se fundamenta, así, en la mala intención y nunca se da sin culpa personal: «Llamamos buena, esto es recta, a la intención por sí misma. A la obra en cambio, la llamamos buena no porque contenga en sí bien alguno, sino porque nace de una intención buena» ${ }^{72}$. Según este esquema se planteaban algunos interrogantes: «Pudiera preguntar alguien si los perseguidores de los mártires o de Cristo pecaban en aquello que creían agradable a Dios» ${ }^{73} \mathrm{o}$ : «QQué culpa se puede imputar a

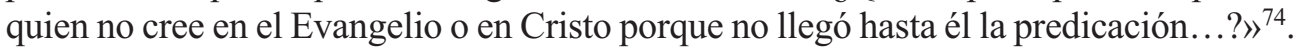
$\mathrm{Y}$, llevando las cosas al extremo: «No pecaron los que crucificaron a Cristo por ignorancia, y cuanto se hace por ignorancia no debe atribuirse a culpa $\rangle^{75}$.

«La verdad es amarga sin el condimento de la gracia» dirá Bernardo de Claraval ${ }^{76}$, uno de los grandes oponentes de Pedro Abelardo a quien acusaba de acomodar a su gusto los dogmas añadiendo o suprimiendo de ellos lo que le placía ${ }^{77}$. Pedro Abelardo seguía en líneas generales la ética de San Agustín pero se distanciaba de él al negar la existencia de un orden moral objetivo. Teólogos posteriores como Santo Tomás contribuirían a crear una doctrina moral más equilibrada que tuviera en cuenta tanto los aspectos objetivos como subjetivos ${ }^{78}$.

Moviéndose en fronteras teológicamente difusas, se situaron quienes sin mala intención propagaron algún tipo de error. Su descubrimiento se podía lograr merced a una especial aplicación del Oportet haereses esse que, merced al debate entre posiciones encontradas, permitiría aclarar alguna cuestión que se presentara confusa. Significativo puede resultar el caso de Joaquín de Fiore, el visionario calabrés renovador del pensamiento histórico ${ }^{79}$. De su santidad nadie dudó pero ello no fue razón suficiente para que después de su muerte (1202), fuese reprobado en el IV Concilio de Letrán. El motivo: achacar a Pedro Lombardo la defensa de una suerte de cuaternidad en Dios: Padre, Hijo, Espíritu Santo y una especie de «esencia común, como una especie de cuarto elemento» ${ }^{80}$. 1939.

${ }^{71}$ Vid. El cap. 2 de J. Rohmer, La finalité morale chez théologiens de S. Augustin à Duns Scot, Paris,

72 Pedro Abelardo, Conócete a ti mismo, p. 48. Un principio del que se hace eco Eloisa al decir que «el crimen está en la intención, más que en el acto»,Cartas de Abelardo y Eloisa. Historia calamitatum. Ed. de P. Zumthor, Barcelona, 1982, p. 95.

73 Pedro Abelardo, Conócete a ti mismo, p. 51.

74 Pedro Abelardo, Conócete a ti mismo, p. 58.

75 «Errores de Pedro Abelardo. Concilio de Sens (1140 o 1141), apendice a Conoceté a ti mismo, p. 151.

76 «Sermón 74 sur le Cantique», recogido en Saint Bernard de Clairvaux. Textes politiques. Ed. de P. Zumthor. Paris, 1986. p. 47.

77 «Lettre 193», en ibid. p. 65.

78 A. Maurer, Filosofía medieval, Buenos Aires, 1967, p. 70.

79 De la abundante bibliografía sobre el personaje resulta útil, aunque no sea el título más relevante, el de D. C. West y S. Zimdars-Swartz, Joaquín de Fiore. Una visión espiritual de la Historia, México, 1986.

${ }^{80}$ «De los errores del abad Joaquín», decreto 2 de «Decretos del IV Concilio de Letrán», en R. Foreville, Lateranense IV, Vitoria, 1972, p. 157. Sobre el papel de Joaquín de Fiore en la opinión de intelectuales de la siguiente generación resulta de interés el estudio de J.I. Saranyana, Joaquín de Fiore y Tomás de Aquino. Historia doctrinal de una polémica. Pamplona, 1979. 
Se adquiere la condición de hereje sólo cuando, tras descubrirse que una proposición es errónea, su autor sigue sosteniéndola contra las advertencias de la autoridad eclesiástica ${ }^{81}$. De ahí que, por ejemplo, con ánimo reconciliador, el mismo Pedro Abelardo en carta a Eloisa pretenda dejar claras sus posiciones frente a las meras conjeturas en las que se basaban sus detractores: «Has de saber que no quiero ser filósofo si ello significa entrar en conflicto con Pablo. Ni ser Aristóteles si ello me aparta de Cristo» ${ }^{82}$.

No en balde, la herejía en la actualidad se define como «la negación pertinaz después de recibido el bautismo, de una verdad que ha de creerse con fe divina y católica, o la duda pertinaz sobre la misma» ${ }^{83}$.

\section{b) La duplex veritas en los «averroístas latinos»}

San Anselmo presentó la verdad como una rectitudo: el lenguaje se amolda al pensamiento; y el pensamiento a la $\cos ^{84}$ Adaequatio rei et intellectus es la definición teológicamente neutra que de la verdad dio la escolástica clásica a través de maestros como Alberto Magno o Tomás de Aquino: «si la verdad es la adecuación de la cosa y el entendimiento, así la falsedad consiste en su desigualdad» dirá el segundo ${ }^{85}$.

La doctrina definida como «averroísmo latino», de la que fueron destacados representantes autores como Siger de Brabante ${ }^{86}$ o Boecio de Dacia, aportaría nuevas visiones.

M. F. Steenberghen habló en su día de «un aristotelismo neoplatonizante, heterodoxo o radical influido a la vez por el averroísmo y el tomismo» ${ }^{87}$. En vez de conciliar a Aristóteles y las Escrituras al estilo tomista, los averroístas latinos aceptaban las contradicciones existentes entre la revelación y la razón natural. Síger de Brabante decía que «por ahora nada tenemos que ver con los milagros de Dios pues nos ocupa-

\footnotetext{
${ }^{81}$ La pastoral católica insistirá en la intencionalidad para fijar las fronteras entre verdad y mentira. Mentir, se dice, consiste en «decir lo contrario de lo que se piensa con intención de engañar». Teológicamente se establece una diferencia, aunque parezca tenue, entre error y mentira. El primero pertenece a la verdad finita «aunque el que yerra falsee la verdad. La mentira, por el contrario constituye un ámbito opuesto a la verdad finita, aunque el que miente conozca a menudo formalmente la verdad», cf. H. Krings, Voz «Verdad. I. Filosofía», en Conceptos fundamentales de la teología t. II, p. 859. Dicho en términos más comunes, el error puede ser inconsciente mientras que la mentira sería el error mantenido con pleno conocimiento de que lo es.

82 «Confesión de fe de Abelardo», apéndice a Conócete a ti mismo, p. 113.

${ }^{83}$ Código de Derecho canónico, Madrid, 1983, p. 347.

${ }^{84}$ San Anselmo, De Veritate 2, 3 Patrología Latina 158, cols. 469-471.

85 Tomas de Aquino, Sobre la verdad, p. 117. Una panorámica sobre el tema en J. Y. Lacoste, «Théologie historique et systèmatique» en la voz «Verité de Dictionnaire critique de théologie (Dir de J. Y. Lacoste). Paris, 2007, pp. 1483ss.

${ }^{86}$ En el Canto X de El Paraíso Dante Alighieri se recoge una relación de sabios que habrían forjado la cultura cristiana y que, cronológicamente, van de Salomón a Siger de Brabante que «enseñando en la calle de la Paja, demostró verdades que despertaron envidias», «La Divina Comedia», en Obras completas ed. de N. González Ruiz, Madrid, 1980, p. 415.

${ }^{87}$ M. F. Van Steenberghen, Siger de Brabant d'aprés ces oeuvres inédites, 2 vols. Inst. Sup. Lovaina, $1931-$ 1942. Una buena visión sobre esta tendencia filosófica en A. Maurer, Filosofía medieval, B1967, pp. 193ss.
} 
mos de las cosas naturales de modo natural» ${ }^{88}$. La tarea del filósofo estaría no tanto en saber cuál es la verdad, sino en escudriñar en el pensamiento de los filósofos y sobre todo en Aristóteles «aun en el caso de que, por azar, el pensamiento del Filósofo no se conformase a la verdad y de que la revelación nos hubiese transmitido, en lo concerniente al alma, conclusiones que la razón natural no pudiese demostrar ${ }^{89}$. Y Boecio de Dacia afirmará que «las conclusiones de los filósofos conciernen a lo naturalmente posible y se fundamentan en razones, mientras que la enseñanza de la fe se apoya con frecuencia en los milagros, no en las razones $\rangle^{90}$.

El obispo de París Esteban Tempier al condenar en 1277 hasta 219 proposiciones sospechosas de herejía, acusaba a los averroístas de defender la existencia de dos clases de verdad (Duplex veritas o duplicidad al menos): «Dicen que algunas cosas son verdades según la filosofía, que no lo son según la fe católica, como si hubiera dos verdades contrarias; como si la verdad de las Santas Escrituras pudiera ser contradicha por la verdad de los textos de esos paganos que Dios ha condenado» ${ }^{91}$. El «Syllabus» del obispo Tempier abría así una profunda brecha entre razón y revelación. El agustino Gil de Roma, otro debelador del averroísmo muerto en 1316, nos diría en su Sobre los errores de los filósofos que el pecado de Aristóteles era un pecado por ignorancia o desde la ignorancia. Por el contrario Averroes, que había renovado todos los errores del Estagirita, había combatido a sabiendas cualquier tipo de revelación ${ }^{92}$.

El prolífico Ramón Llull, uno de los grandes luchadores contra el averroísmo, destacaría el valor contagioso de la mentira («a causa de un embustero, otros también mienten» ya que «un embustero crea embusteros») y la perfidia social de aque-

${ }^{88}$ En De Anima Intellectiva, 3, ed de P. Mandonnet, Siger de Brabant et l'averroisme latin au XIII siècle vol. 2 ; Les philosophes belges, VII, Institut Supérieur, Lovaina, 1908, p. 154.

${ }^{89}$ De Anima Intellectiva, 7, p. 164.

${ }^{90}$ Sobre Boecio de Dacia vid. E. Gilson, «Boèce de Dacie et la double verité», en Archives d'Histoire Doctrinale et Litteraire du Moyen Âge, 22 (1956) pp. 81-99, A. Maurer, « Boetius of Dacie and the Double Truth» en Medieval Studies 17 (1955) pp. 233-239, y G. Sajo, «Boèce de Dacie et les commentaires anonymes inédites de Munich sur la physique et sur le génération attribués a Siger de Brabant », en Archives d'Histoire Doctrinale et Litteraire du Moyen Âge, 33 (1958) pp. 21-58. Mucho después que los autores averroistas lord Edward Herbert de Cherbury, considerado uno de los pioneros del deísmo en la historia del Occidente, daría a la luz la estimada como primera metafísica verdadera de la Inglaterra moderna: De veritate prout distinguitur a revelatione, a verosimili, a possibili et a falso, publicada en París en 1624 (en Londres lo sería en 1645). Su objetivo era ocuparse de las verdades de la Razón, «pues las de la Fe deben ser consideradas desde un punto de vista propio». Las «veritates aeternae» se imponen en nuestro «fuero interno» y nos hacen apreciar que «nunca pudo ser de otra manera» y por tanto se distinguen de las verdades experimentales. Vid. comentario de G. Pioli en voz «De la verdades en cuanto se distingue de la revelación, de lo verosímil, de lo posible y de lo falso» en Diccionario literario, t. X, Barcelona, 1957, pp. 476-477. Unos años después (1674-1675), el filósofo y teólogo francés Nicolás Malebranche dio a la luz un De la Recherche de la verité (Version Española Acerca de la investigación de la verdad. Ed. De J. Martín Barinaga.Rementería. Salamanca 2009) en donde, después de analizar las fuentes de nuestros errores, producto de un mal uso de la voluntad, proponía un método en ocho reglas para alcanzar la verdad.

91 A. Libera, Pensar en la Edad Media, Barcelona, 2000, p. 56 y 121-126. Sobre la condena de 1277 vid. el texto comentado por R. Hissette, Enquète sur les 219 articles condamnés à Paris le 7 de mars 1277, Louvain- Paris, 1977 y L. Bianchi, Il Vescovo e i filosofi. La condamna parigina del 1277 e l'evoluzione dell'aristotelismo scolastico, Bergamo, 1990.

92 A. Libera, -op. cit., p. 99. 
llos que practican la mentira («quien miente roba la verdad a aquellos que le escuchan»). Sin embargo, suavizando este juicio, advertiría que pocos eran conscientes de sus mentiras ${ }^{93}$.

Al margen de la influencia (o de la existencia misma) del averroísmo cara a la filosofía pura, hubo un campo en el que éste daría importantes frutos: el de la teoría política con figuras como Juan de Jandun quien influiría poderosamente sobre Marsilio de Padua y su Defensor pacis (1324) obra repleta de invocaciones a la figura de Aristóteles. A partir de este momento, se ha dicho, el estado sale de la tutela de esa trascendencia agustiniana ${ }^{94}$ definida por algunos como agustinismo político ${ }^{95}$. Para Marsilio lo natural y lo sobrenatural gozaban de plena autonomía de forma que, tratándose del gobierno civil, nada tenían en común. En lo concerniente al estado lo que interesaba era solamente el cuerpo político ${ }^{96}$. La parte sacerdotal del estado está «fundada en la tradición divina o revelación inmediata, pero imposible de ser probada por la razón humana» ${ }^{97}$.

\section{c) De la escolástica al Renacimiento}

La inmodestia en la interpretación de las verdades de fe podía dar pie a una reprobación como la sufrida por el difícilmente encuadrable maestro Eckehart: ¿místico? ¿escolástico? ¿predicador insigne? ¿alumno pero no discípulo de Alberto Magno y Tomás de Aquino? ${ }^{98}$. En 1329, dos años después de muerto, se condenaron veintiocho proposiciones extraídas de sus escritos ya que «quiso entender más de lo que fuera necesario y con inmodestia y sin someterse al módulo de la Fe, apartó su oído de la verdad, entregándose a la ficción ${ }^{99}$. Difícilmente en los círculos más oficiales se admitía una libre especulación a la que se tachaba con frecuencia de pura vanidad.

En el ocaso del Medievo, el cardenal Nicolás de Cusa (1401-1464) hará la figura de un destacado intelectual también de difícil clasificación dada su fabulosa erudición

\footnotetext{
${ }^{93}$ Ramon Llull, Provervis de Ramón. Ed. de S. Garcías Palou, Madrid, 1978, p. 461.

${ }^{94}$ F. Bataglia, Marsilio de Padova e la filosofia politica del Medio Evo, Firenze, 1928, p. 251. Todavía de gran interés para el estudio de este autor resulta la lectura de G. Lagarde, Marsile de Padoue ou le prémier theoricien de l'Etat laïque vol II de La naissance de l'esprit lä̈que au dèclin du Moyen Age. Saint-PaulTours Chateaux, 1934 (monumental obra objeto de varias reediciones, la última de París-Lovaina 1970) . Muy justificadamente citada es la monografía de J. Quillet, La philosophie politique de Marsile de Padoue, Paris, 1970. Una panorámica sobre este autor y la polémica suscitada, objeto de la condena pontificia, en E. Mitre, Iglesia, herejia y vida política en la Europa medieval, Madrid, 2007, pp. 120-122.

${ }_{95}$ Cf. El clásico de H. X. Arquillière, L'augustinisme politique, Paris, 1955 (original de 1933). Sobre el tema existen otros aportes como el de E. Gilson, Les métamorphoses de la cité de Dieu, Paris, 1952 (versión española Madrid, 1965) o el de M. García Pelayo, El reino de Dios, arquetipo político, Madrid, 1959.

${ }^{96}$ W. Ullmann, Historia del pensamiento político en la Edad Media, Barcelona, 1983, p. 196.

${ }^{97}$ Rótulo del cap. VI de la primera parte de Marsilio de Padua, El defensor de la paz. Ed. de Luís Martínez Gómez. Madrid, 1989 p. 25.

${ }^{98}$ Algunas interesantes observaciones sobre este autor y en especial sobre sus relaciones con el beguinismo, en A. Libera, op. cit., pp. 249-274.

99 «Bula de Juan XXII In Agro Domino de 27 de marzo de 1329», apéndice a Libro del Consuelo divino, Ed. de A. Castaño, Buenos Aires, 1977, p. 81.
} 
y su interés por todos los acontecimientos científicos, filosóficos y teológicos de su época. Un mundo entre el Medievo y el Renacimiento ${ }^{100}$.

Su conocida obra De la docta ignorancia constituiría un importante capítulo en la historia de la delimitación del campo del conocimiento y, consiguientemente, de la verdad. Partiendo de la base de que «tanto más docto será cualquiera cuanto más se sepa ignorante» ${ }^{101}$ el Cusano popularizó una imagen. Será la de nuestro conocimiento mental (adaequatio) equiparado a un polígono que, por muchos lados que se le añadan, sólo podrá lograr una aproximación infinita a un círculo en el que se le quiera inscribir (símbolo de la verdad) pero nunca podrá identificarse totalmente con é ${ }^{102}$. «Entre la verdad y el conocimiento humano existe el principio de la inconmesurabilidad» ha escrito uno de los especialistas en la figura del Cusano ${ }^{103}$.

Su pensamiento, en lo que concierne a la visión de la verdad, lo complementan otros textos como La paz de la fe y las misivas intercambiadas con el maestro de la Universidad de Salamanca Juan de Segovia. Se trata de textos redactados bajo el impacto de la toma de Constantinopla por Mahomet II en 1453, un acontecimiento al que se ha otorgado la condición de bisagra entre dos edades de la Historia ${ }^{104}$. No se hace en estos escritos una llamada a la guerra para la derrota del infiel siguiendo el añejo espíritu cruzadista, sino que se aboga por una suerte de concordia entre religiones, facilitada por una circunstancia: todos los hombres, a su modo, participan de unos sentimientos espirituales comunes y pueden acceder a la Verdad en su más alto sentido a través de una serie de peldaños. El Cusano pensaba que el Islam podría admitir, debidamente explicadas, grandes verdades de la fe cristiana como las correspondientes a la Trinidad, la Encarnación o la Eucaristía ${ }^{105}$. El espíritu dialogante del cardenal, pese a las afirmaciones de quienes le consideran en la actualidad un adelantado del ecumenismo, no admitía sin embargo «varias verdades»; simplemente manifestaba su confianza en «la fuerza de convicción de la verdad cristiana» ${ }^{106}$.

En una línea parecida se manifestó años después uno de los grandes humanistas: Erasmo de Rotterdam campeón del irenismo en una Europa convulsionada por las rivalidades entre los príncipes cristianos, los inicios de la Reforma protestante y el peligro otomano ${ }^{107}$. A su juicio, el ejemplo del cristiano y no la cruzada era la mejor arma

${ }^{100}$ Cf. Para ello los trabajos recogidos por E. Colomer, De la Edad Media al Renacimiento. Ramon Llull. Nicolas de Cusa, Pico Della Mirandola, Barcelona, 1975.

101 Cusa, La docta ignorancia. Ed. de M. Fuentes Benot, Barcelona, 1984, p. 24.

102 «Propiamente todo conocimiento es sólo conjetura» afirma H. Hirschberger, al referirse al pensamiento de Cusa, Breve historia de la filosofia Barcelona, 1971, p. 153.

${ }^{103}$ K. Flasch, Nicolás de Cusa, Barcelona, 2003, pp. 24 y 120.

${ }^{104}$ Un texto ya clásico sobre el tema es el de S. Runciman, La caída de Constantinopla. Ed. española de 1973 sobre el original de Cambridge de 1965. De gran interés son, asimismo, las actas del congreso Constantinopla 1453. Mitos y realidades (Ed. de P. Bádenas e I. Pérez Martín), Madrid, 2003.

${ }_{105}$ Nicolás de Cusa, La paz de la fe. Carta a Juan de Segovia. Ed,. de V. Sanz Santacruz. Madrid, 1999, p. 66-70. En otro texto bajo el título Cribratio Alcorani (El Corán cribado) el cardenal defendía puntos de vista similares.

106 E. Colomer, «Nicolás de Cusa, un pensador», recogido en De la Edad Media al Renacimiento, p. 138.

${ }^{107}$ Una biografía clásica sobre el personaje aún de utilidad sigue es la de J. Huizinga, Erasmo Barcelona, 1970 (ed. or. 1925). 
para inducir a las gentes de otros credos religiosos a entrar en la senda de la verdad que, desde un punto de vista del cristiano, no debía imponerse por la fuerza. Sólo en casos extremos - una manifiesta agresión llevada a cabo por los turcos- se justificaría el recurso a las armas. Ante ellas nuestro autor expresó siempre un cierto recelo, o al menos ambigüedad tal y como manifiesta en su Consultatio de bello turcico (c. 1530) ${ }^{108}$.

\section{d) Los perfiles de la verdad histórica}

Para Isidoro de Sevilla, la Historia era «la narración de los hechos acontecidos, por la cual se conocen los sucesos que tuvieron lugar en tiempos pasados». Siguiendo a los clásicos, de los que el Hispalense se hacía receptor (¿cultura o mera erudición clásica? ${ }^{109}$ ) la historia la integran «hechos verdaderos que han sucedido», los argumentos son «sucesos que no han tenido lugar, pero pueden tenerlo» y las fábulas «en cambio son aquellas cosas que ni han acontecido ni pueden acontecer porque son contrarias a lo natural» ${ }^{110}$.

De acuerdo con esta idea de raíz ciceroniana, los historiadores del Medievo -advierte Bernard Guenée- quisieron, al igual que nosotros, encontrar la verdad. Sin embargo, fueron casi siempre a remolque de la teología y del derecho y dependieron de un sistema crítico que se basaba en una jerarquía de autoridades ${ }^{111}$.

Dentro de ésta se encontraban en lugar preferente los textos escriturarios. Los cristianos podrían haber rechazado sin más los correspondientes al Antiguo Testamento por ser demasiado contrarios en numerosas ocasiones al espíritu del Evangelio. No lo hicieron sino que los integraron en su herencia cultural dando a sus pasajes un sentido más allá de lo puramente literal ${ }^{112}$. Dentro del plan divino de Salvación -que a fin de cuentas daba sentido al discurrir de la Historia ${ }^{113}$ - los textos veterotestamentarios (como la propia historia de la Roma pagana) eran una suerte de propedéutica para el proceso abierto con la Encarnación-Redención. El Nuevo Testamento se erigía en complemento y cumplimiento del Antiguo ${ }^{114}$.

San Agustín dejaría escrito que «no nos toca saber los tiempos que el Padre puso en su potestad» ${ }^{115}$. Y San Isidoro a su vez afirmaría que «cuanto tiempo resta de esta

\footnotetext{
${ }^{108}$ Desarrolla ahí parte de uno de los proverbios («El pretexto de la Guerra contra los turcos») recogidos en Erasmo, Adagios del poder y de la guerra. Ed. de R. Puig de la Bellacasa. Madrid, 2008, pp. 241ss.

109 Vid. a este respecto las reservas de M. C. Diaz y Diaz, De Isidoro al siglo XI, Barcelona, 1976. Más favorable en cuanto a los aportes del personaje-es el hispanista francés J. Fontaine, autor de distintos trabajos sobre su figura y su obra. Entre los últimos, la síntesis Isidoro de Sevilla. Génesis y originalidad de la cultura hispánica en tiempos de los visigodos. Madrid, 2002.

${ }^{110}$ San Isidoro de Sevilla, Etimologías. I. 41-44. Ed. de J. Oroz Reta y M. C. Diaz y Diaz. T. I. Madrid, 1982, pp. 359-361.

111 B. Guenée, Histoire et culture historique dans l'Occident médiéval, Paris, 1980, p. 147.

112 Ibid. p. 19.

113 E. Mitre, Historiografia y mentalidades históricas en la Europa medieval, Madrid, 1982, p. 47.

114 Ibid. p. 32-36. Sobre la cristianización de la Historia de Roma vid. H. Inglebert, Les romains chrétiens face a l'histoire de Rome. Histoire, christianisme et romanités en Occident III-V siècles, Paris, 1996.

115 San Agustín, La Ciudad de Dios, lib. XXII, cap. 30. Ed. de F. Montes de Oca. México, 1978, pp. 601603 .
} 
sexta edad, solo Dios lo sabe» ${ }^{116}$. De acuerdo a ello, ninguna mente humana tendría capacidad para fijar en qué momento había de producirse la culminación de la historia. Frente a esta idea -o matizándola al menos- jugarían con cronologías varias distintos autores que especularon en torno al fin de los tiempos ${ }^{117}$. Bien ellos o bien sus doctrinas se verían abocados a la desaprobación oficial. El mencionado caso de Joaquín de Fiore resulta el más representativo en el Medievo aunque no sea el único ${ }^{118}$.

El esquema definido como «biblia historial», narración basada en la Historia Sagrada con noticias referidas a otros pueblos, sería utilizado para cualquier intento de elaborar una Historia Universal acometido a lo largo del Medievo. Se aplica preferentemente a la Historia scholastica de Pedro Coméstor redactada en el siglo XII y que constituyó un libro de texto extraordinariamente difundido en los medios académicos ${ }^{119}$. Algunos lo han aplicado también a la General estoria, el magno proyecto inacabado de Alfonso X. La datación bíblica acabaría constituyendo la espina dorsal de compilaciones históricas de sentido universal. Para el rey Sabio la hebraica veritas suponía «una historia de importancia muy superior a cualquier otra y, por consiguiente, se ofrecía como forzoso punto de partida» ${ }^{120}$.

La verdad histórica para el cristiano que esgrimía diferentes textos -en lugar preferente aquellos en que basaba su fe-se condicionaba por dos circunstancias.

En primer lugar, estaba la interpretación de los pasajes escriturarios -especialmente los del Antiguo Testamento- que permitía crear una verdad teológica que trascendía la mera literalidad de los textos ${ }^{121}$. Aunque muchos pasajes podían resultar fantasiosos, admitían (según los exegetas de la escuela de Alejandría en los primeros tiempos de la Iglesia) hasta cuatro sentidos distintos. El puramente literal se remetía sin matices a lo escrito, sin lecturas de otra naturaleza. El sentido alegórico se basaba en la calidad simbólica y figurada. El sentido moral facilitaba al creyente ejemplos de vida ocultos en el texto. Por último, quedaba el sentido más alambicado que era el anagógico: el que permitía abordar los pasajes de las Escrituras desde una valoración mística $^{122}$. Analistas de los libros veterotestamentarios del pasado siglo hablaron de diferencias entre «historia real» basada en la cronología y en la geografía, y la «historia primitiva», con numerosos elementos legendarios y en un punto medio entre historia real y el mito. A ella pertenecería el período comprendido entre la creación y la venida de Jesucristo ${ }^{123}$.

\footnotetext{
116 San Isidoro, Etimologías, V. 29.

${ }^{117}$ Los apocalípticos interpretaron la historia, pasada o presente, en la medida en que estas preparaban el fin de la historia. M. Delcor, Mito y tradición en la literatura apocaliptica, Madrid, 1977, P. 45.

118 Vid. el compendio glosado de C. Carozzi y H. Taviani-Carozzi (Prefacio de G. Duby) La fin des temps. Terreurs et prophéties au Moyen Âge, Paris, 1982.

119 S. R. Daly, «Peter Comestor: Master of Historiens», en Speculum 32 (1957) pp. 62-73.

${ }^{120}$ F. Rico, Alfonso el Sabio y la «General estoria», Barcelona,1972, pp. 49-52.

121 Vid. lo recogido en nota. 40.

${ }^{122}$ Vid. Para este tema el estudio de H. de Lubac, L'Éxegesse médiévale. Les Quatre sens de l'Ecriture, Paris, 1959-1961.

${ }^{123}$ J. L. Mc Kenzie, Mito y realidad en el Antiguo Testamento, Madrid, 1971. p. 86, recogiendo ideas sustentadas por M. J. Lagrange y F. Feldmann.
} 
En segundo lugar, para el hombre del Medievo la verdad histórica se condicionó durante siglos a que la Historia -como la Filosofía en general - fuera una ancilla theologiae, la ciencia por excelencia. Con el tiempo derivará en ancilla scientiae politicae ${ }^{124}$. Transcurridos varios siglos L. Ranke, desde el estricto positivismo, lanzaría el popular aforismo sobre la misión de la Historia: «mostrar los hechos tal y como sucedieron» ${ }^{125}$.

\section{LA VERDAD AL ALBUR DE LA ORDALÍA}

Estamos ante un procedimiento de raíz eminentemente bárbara que implica la fe en la intervención mágica de la divinidad. Se dará en la Europa Medieval pero también, se ha destacado, en otras civilizaciones ${ }^{126}$.

\section{a) Entre la aceptación y la reserva}

Ante el expediente de la ordalía las opiniones de las autoridades eclesiásticas no fueron unánimes. Así, en la Francia del siglo IX Hincmaro de Reims se mostraba favorable mientras que Agobardo de Lyon consideraba esta costumbre como algo cercano a la idolatría ${ }^{127}$. Según J. Paul, la ordalía «no es sino el ritual de la interrogación del cielo llevado a su paroxismo» ${ }^{128}$.

El trascendental IV Concilio de Letrán (1215), trató de imponer una cierta racionalidad: prohibirá a los eclesiásticos dictar o ejecutar sentencias de muerte y «conceder bendición o consagración a las ordalías, ya se realicen por el hielo o el agua hirviendo o por el hierro candente; siguen conservando todo su vigor las prohibiciones ya anteriormente dictadas y que se refieren a los combates particulares o duelos» ${ }^{129}$. Estas normas acabarían imponiéndose en el conjunto de los estados del Occidente ${ }^{130}$.

\footnotetext{
124 B. Guenée, Histoire et culture historique, p. 36.

125 «Er will bloss zeigen wie es eigentlich gewesen». Sobre la historia como fría ordenación de acontecimientos perfectamente verificados recogimos algunas observaciones en E. Mitre, Historia y pensamiento histórico. Estudio y antología, Madrid, 1997, pp. 90-93.

${ }^{126}$ La prueba del fuego y el agua se percibe, por ejemplo, en sociedades tan distintas como la Babilonia de Hammurabi, Kenia, la Polinesia o el Japón. R. Bartlett, Trial by Fire and Water. The Medieval Judicial Ordeal, Oxford, 1986, p. 2. Buena introducción al tema en J. Gaudemet, «Les ordalies au Moyen Age: doctrine, législation et pratique canonique», en Recueils de la Societé Jean Bodin, XVII. La preuve II, Bruselas, 1965, pp. 99ss.

${ }^{127}$ D. Barthelemy, Caballeros y milagros. Violencia y sacralidad en la sociedad feudal. Valencia-Granada, 2006, p. 232.

128 J.Paul, La Iglesia y la cultura en Occidente (siglos IX-XII) 2/ El despertar evangélico y las mentalidades religiosas, Barcelona, 1988. p. 525.

129 «Decretos del IV Concilio de Letrán» (Decreto 18) en R. Foreville, Letrán IV, Vitoria, 1973, p. 173. El declive de los juicios de Dios se apreciaría ya desde 1100. D. Barthelemy, op. cit., pp. 252 y ss.

${ }^{130}$ Para R. Bartlett, la ordalía por el agua y el fuego era de uso común en la cristiandad latina. Hacia 1300 tan sólo quedarán de ella simples vestigios. Trial by fire and water, p. 34. La tortura judicial será una de sus principales alternativas: la primera referencia legislativa sobre ella se recoge en el Liber Juris civilis de Verona en 1228. ibid. p. 139.
} 
Algunos trabajos recientes, sin embargo, han manifestado sus reservas en cuanto a la rápida sustitución de los procesos de pura trascendencia «que buscan la verdad por caminos que la razón no muestra» por procesos de naturaleza romano-canónica ${ }^{131}$.

El duelo judicial planteado como ordalía se encuentra en las leyes primitivas de muchos pueblos germánicos: burgundios, lombardos, alamanos, bávaros, turingios, frisones y sajones ${ }^{132}$ desde donde se convertirá en práctica bastante común en el conjunto del Occidente altomedieval.

\section{b) El resultado de la batalla como sentencia de Dios}

Este especial espíritu puede percibirse también a nivel de la batalla a campo abierto entre dos rivales de cierto rango; una especie de duelo judicial de muy alto fuste. La propaganda política y la historiografía más áulica acabaron otorgando al vencedor no sólo la razón sino también un especial prestigio histórico. Ocurrirá con Clodoveo quien aún pagano y enfrentado en Tolbiac con los alamanos (c. 494) invoca al Dios de su mujer, la católica Clotilde, a quien promete fidelidad si le premia con la victoria $^{133}$. Siglos después lo veremos en la victoria de Simón de Montfort en Muret (1213) contra Pedro II de Aragón protector de vasallos filocátaros aunque él fuera ferviente católico ${ }^{134}$. Y cabe apreciarlo también con el triunfo de Felipe Augusto de Francia en Bouvines (1214) frente a un abigarrado ejército encabezado por el excomulgado emperador Otón de Brunswick ${ }^{135}$. Tres ejemplos entre otros muchos de un Medievo que plantea las batallas como auténticas psicomaquias. Las victorias militares aparecen en la cultura cristiana del Medievo como una obra de Dios ${ }^{136}$. Las cruzadas, no lo olvidemos, son las gesta Dei per francos es decir, los hechos que Dios realiza a través de los francos, entendiendo por tal el conjunto de los cristianos occidentales como una suerte de pueblo elegido, el nuevo (o verus) Israel ${ }^{137}$.

El campo de batalla o sus sucedáneos pueden hacer también de la mentira estigma que marque ciertos deshonrosos comportamientos. Sucedió, por ejemplo en 29 de junio de 833 cuando el emperador Luís el Piadoso fue ignominiosamente abandonado por sus soldados que se pasaron al bando de sus hijos rebeldes. Una situación que forzó al soberano a una penitencia pública en San Medardo de Soissons para ex-

131 Para el estudio de este tema en los fueros castellanos y en la legislación alfonsí. M. Madero, Las verdades de los hechos. Proceso, Juez y testimonio en la Castilla del siglo XIII. Salamanca, 2004, p. 44.

${ }^{132}$ Lo que R. Bartlett llama el «trial by battle», Trial by Fire and Water, p. 103 y ss.

133 Gregoire de Tours, Histoire des Francs. Ed. de R. Latouche. Vol. I. Paris, 1999 (reimpresión del original de 1963) pp. 119-120.

134 Vid. para ello la monografía de M. Alvira Cabrer, 12 de septiembre de 1213. El jueves de Muret, Barcelona, 2002 especialmente pp. 229ss.

135 Vid. el modélico trabajo de G. Duby, Le dimanche de Bouvines, Paris, 1973.

136 Así en el Cantar de Mío Cid. Cf. M. R. Lida de Malkiel, La idea de la fama, p. 126.

${ }^{137}$ La cruzada se plantea como realización de la voluntad divina (Deus lo volt, Dios lo quiere) P. Contamine, «Una guerre pour le royaume des cieux», en Les croisades. Ed. de R. Delort. Paris, 1988, p. 99. Un reciente estudio sobre la cobertura ideológica y mental de la cruzada lo facilita el libro de J. Flori, La guerra santa. La formación de la idea de cruzada en el Occidente cristiano, Madrid-Granada, 2003. 
piar los yerros cometidos. La tradición cambiaría el nombre del lugar cercano a Colmar en el que se produjo el vergonzoso hecho: de Rothfeld (Campo Rojo) a Lügenfeld o Campo de la Mentira ${ }^{138}$.

Y ¿qué decir de ese desafío de Carlos de Anjou a Pedro III de Aragón en 1282 para solucionar con un duelo entre los dos monarcas (acompañados de sendos séquitos de cien caballeros) el contencioso que les enfrentaba por la posesión del reino de Sicilia? Un choque que no se llegaría a celebrar, que alarmó al papa Martín IV ya que, como representante de Dios en la tierra se consideraba como máximo árbitro en cualquier disputa entre cristianos, y de cuyo fracaso ambos contendientes declararon responsable a su rival. El que el pontificado acabase tomando partido por los angevinos al predicar una cruzada contra Aragón acabaría tergiversando una idea puesta al servicio -una vez más- de los intereses temporales de los papas ${ }^{139}$.

\section{c) Otras formas de ordalía}

La filosofía de la ordalía ${ }^{140}$ se trasladará más allá de las relaciones puramente personales -individuales o colectivas-a fin de comprobar la verdad en otros terrenos. En cualquier caso, para dejar en desairado lugar a un rival cuya mendacidad se desea poner de relieve.

Ocurrirá en el ámbito de la autentificación de las reliquias, cuyo culto y tráfico (robo en numerosas ocasiones) estuvo extraordinariamente difundido en el Medievo $^{141}$. Tal situación se dará en el II concilio provincial de Zaragoza de 592; tres años después de la celebración del concilio III de Toledo en el que Recaredo proclamó la ortodoxia nicena como religión de Estado. Se ordenó usar la prueba del fuego para aquellas reliquias que, depositadas en iglesias antes ocupadas por arrianos, podían resultar en principio de sospechosa autenticidad ${ }^{142}$.

No será la única medida contra su desaforado culto. Contamos con otros ejemplos que se mueven dentro de una mayor racionalidad. Así, algunos autores como el abad Guiberto de Nogent (mediados del siglo XII) denunciarán el abuso de este culto y el afán mercantilista de establecimientos monásticos que usaban supuestas reliquias como incentivo para movilizar la piedad de los peregrinos ${ }^{143}$. Y, unos años después, el IV Concilio de Letrán prohibió venerar reliquias que no contaran con la autorización de

\footnotetext{
138 Recogido en L. Halphen, Charlemagne et l'empire carolingien, Paris, 1968, pp. 246-247.

139 Una descripción de esta curiosa historia la recoge el cronista Ramón Muntaner, en su popular Crónica. Ed. castellana de J. F. Vidal Jové Madrid 1970 pp 139 y ss. Una buena síntesis en S. Runciman, en su conocido Las vísperas sicilianas, Madrid, 1961, pp. 225ss.

140 Sobre su pervivencia en los discursos y en niveles sociales elitistas, vid lo recogido por M. Madero, «El duellum entre la honra y la prueba» en Las verdades de los hechos, pp. 101ss.

${ }^{141}$ Un título de referencia para el tema, aunque volcado esencialmente en la plenitud del Medievo, lo constituye el de P. J. Geary, Furta Sacra. Thefts of relics in the Central Middle Ages. Princeton Univ. Press, 1978.

142 «Concilio de Zaragoza II» canon II. En Concilios visigóticos e hispano-romanos. Ed. de J. Vives, T. Marín y G. Martínez Díez, Barcelona-Madrid ,1963, p. 154.

${ }_{143}$ Guibertus abbas monasterii S. Mariae Novigenti: De pignoribus Sanctorum. Patrología Latina, CLVI, cols. 607-680.
} 
Roma y advirtió a los rectores de las iglesias para que los fieles que acudieran a ellas no fueran «engañados por vanas imaginaciones o falsos documentos como ha ocurrido en muchos lugares con motivos de lucro» ${ }^{144}$. Una medida que, como tantas otras, sería de efectividad limitada.

Los hagiógrafos nos hablarán también del expediente de la ordalía -por el fuego en este caso aplicado a textos religiosos. Muy conocida es la tradición de la conferencia entre ortodoxos y heréticos mantenida en Fanjeaux en 1207: ante la cerrazón de los dos bandos, se echaría mano de la prueba del fuego. Éste hizo saltar fuera de la hoguera los textos católicos redactados por Santo Domingo de Guzmán a la vez que hizo arder los aportados por los cátaros. Ello mostró a las claras, dice el hagiógrafo, «cuál era la verdadera fe y cuán grande era la santidad de su autor» ${ }^{145}$.

\section{PROYECCIÓN SOCIAL DE LA DIALÉCTICA VERDAD/MENTIRA EN EL DEBATE HERESIOLÓGICO}

Acusar de falso o mentiroso al «otro» buscará no sólo desprestigiarlo; también resaltar algunas cualidades que se pretenden propias ${ }^{146}$. Se trata de unos mecanismos alejados con frecuencia del mundo más estrictamente académico ${ }^{147}$.

a) Los juicios que determinadas personas o comunidades merecen a la «otra» parte... y se merecen de sí mismas

Entraríamos aquí en una óptica sin duda de limitado calado teológico pero sociológicamente ambiciosa, más allá de las opiniones y actuaciones puntuales. Pueden resultarnos útiles varios ejemplos en los que las versiones de católicos y heréticos (o culpados de tal) unas veces entran en oposición y otras acaban moviéndose con puntos de vista similares.

En primer lugar estaría el uso de textos declarados apócrifos una vez que el canon escriturario fue fijado por la autoridad eclesiástica ${ }^{148}$. El caso de Prisciliano, que se ha prestado a opiniones harto encontradas (¿hereje? ¿reformador? ¿difusor de cierta

\footnotetext{
144 «Decretos del IV Concilio de Letrán. 62», en Lateranense IV, p. 198.

145 Beato Jordán de Sajonia, «Orígenes de la orden de predicadores» en Santo Domingo de Guzmán. Su vida, Su obra. Sus escritos, Ed. de M. Gelabert, J. M. Milagro y J. M. Garganta. Madrid, 1966, p. 156. Este milagro se narra en términos muy parecidos en Pedro Ferrando, «Leyenda de Santo Domingo», en ibid. p. 301. Para una breve evaluación de esta leyenda, E. Mitre y C. Granda, Las grandes herejías de la Europa cristiana, Madrid, 1999, p. 134.

${ }^{146}$ A propósito de estos mecanismos vid. las interesantes reflexiones recogidas por E. Benito Ruano, De la alteridad en la Historia. R.A.H. Madrid, 1988.

${ }^{147}$ De fecha reciente es el llamativo libro de K. Sullivan, Truth and the Heretic: Crises of Knowledge in Medieval French literature. Chicago, 2005. Por literatura entiende esta autora aquella producción al margen del didactismo clerical que «permite a la sociedad medieval expresar verdades en torno a los herejes y a las ansiedades que surgen y que no pueden ser expresadas de otra manera», p. 16.

${ }^{148}$ Para una valoración de los textos apócrifos vid. A. Piñero, voz «Apócrifos», en Nuevo Diccionario de Teología (Ed. de J. J. Tamayo). Madrid, 2005, p. 51.
} 
forma de ascesis? ¿criptomaniqueo? ${ }^{149}$ ) resulta significativo en tanto, frente a las acusaciones de sus rivales, se posiciona contra «la novedad (que) es madre de la disensión y del ingenio». Y en tanto advierte de lo peligroso que es si «cada cual sigue a su ingenio más que a Dios» ${ }^{150}$. La iniciativa personal e incontrolada en el campo espiritual acaba por ser homologada con la falta a la verdad.

La cultura antiherética facilitará siglos más tarde abundante material sobre los cátaros, los herejes por excelencia del Medievo ${ }^{151}$. Su ciudad más importante, capital del Midi, sería calificada por los polemistas católicos de Tolosa-Dolosa. Es solamente una de las múltiples invectivas lanzadas contra poblaciones de la región acusadas de una especial mala $\mathrm{fe}^{152}$. Unas críticas a las que, desde el lado cátaro, o simplemente occitano, se responde con dicterios similares que enlodan la imagen de franceses y clérigos ${ }^{153}$.

Moneta de Cremona, para denunciar la falsedad de las doctrinas cátaras, las define de cogitationes evanescentes, fabulae ineficaces, fantasticae rationes invenciones, etc... ${ }^{154}$.

También desde el lado de la ortodoxia se denuncia a sus oponentes por atribuir a los católicos creencias y doctrinas basadas en un cúmulo de falsedades. Pierre de Vaux de Cernay, autentico «corresponsal de guerra» del ejercito cruzado de Simón de Montfort ${ }^{155}$, nos dice que los herejes del Sur de Francia tildaban al autor del Antiguo Testamento de mentiroso y declaraban condenados a todos los Padres veterotestamentarios hasta Juan el Bautista a quien consideraban uno de los principales demonios ${ }^{156}$. Algunos años más tarde el inquisidor Rainiero Sacconi se manifestará de forma similar al decir que, según los heréticos, el diablo era el autor de todo el Antiguo Testamento, declarando con ello «enemigos de Dios y ministros del diablo» a Abraham, Isaac, Jacob, Moisés y el Bautista. Sólo aquellos pasajes insertados en el Nuevo Testamento se podrían considerar como verdad ${ }^{157}$.

\footnotetext{
149 Sobre estas variantes una cómoda guía la facilita la síntesis de H. Chadwick, Prisciliano de Ávila. pp. 85ss.

${ }^{150}$ Prisciliano, «Libro sobre la fe y los apócrifos», en Tratados y cánones. Ed. de B. Segura Ramos. Madrid, 1975. pp. 63ss. Sobre el uso de apócrifos por los heréticos vid. las acusaciones recogidas en el «I Concilio de Braga de 561», en Concilios visigóticos e hispano-romanos. p. 66.

${ }^{151}$ Hasta el extremo de que, una importante y reciente monografía sobre el tema ha hablado de esta herejía en plural. P. Jiménez, Les catharismes. Modèles dissidents du christianisme médiéval (XII-XIII siècles). Presses Universitaires de Rennes, 2008. A los cátaros y a los herejes en general del Mediodía de Francia dedica un amplio espacio K. Sullivan en los capítulos 2 («The secrecy of the manicheans and cathars») op. cit., pp. $47-$ 83; y 6 («The duplicity of the waldesians») ibid. pp. 186-216.

${ }^{152}$ E. Mitre y C. Granda, Las grandes herejías de la Europa cristiana. pp. 135 y ss.

153 Vid. la excelente edición coordinada por Jordi Savall en la que se recogen, en siete lenguas, breves visiones de distintos especialistas y un importante elenco de poemas y canciones trovadorescas: Le Royaume oublié. La croisade contre les albigeois. La tragédie cathare, Aliavox , 2009.

${ }^{154}$ L. Polini, «Italian catharisme and written culture » en Heresy and Literacy 1000-1530. Ed, de P. Biller y A. Hudson, Cambridge, 1996, pp. 85-86.

155 Sobre la cronística de la cruzada vid, entre otros, el viejo pero todavía útil trabajo de Y. Dossat, «La croisade vue par les Chroniqueurs», en Paix de Dieu et guerre Sainte en Languedoc au XIII siècle. Cahiers de Fanjeaux 4. Toulouse, 1969, pp. 222-259.

156 Pierre des Vaux-de-Cernay, Histoire Albigeoise. Ed. de P. Guebin y H. Maisonneuve, Paris, 1951, p. 5

157 Raynier Sacconi, « Summa de Catharis» ed. de F. Sanjek, «Raynerius Sacconi O.P. Summa de Catharis», en Archivum Fratrum Praedicatorum 44 (1974). Ed. francesa de Jean Duvernoy bajo el título «Frere Raynier de l'Ordre des fréres Précheurs. Des Cathares et des pauvres de Lyon» p. 7 y 10.
} 
Una figura extendida en los medios ortodoxos es la del defensor de la fe objeto de falsedades por parte de los herejes. Santo Domingo de Guzmán sería -de acuerdo a esta visión- una de las dianas favoritas tal y como destacan algunos de sus hagiógrafos: «iCuántas injurias sufrió en aquellos días de parte de los malvados! ${ }^{158}$; «y al paso que (los herejes) le escarnecían y proferían injurias contra él desde el pésimo tesoro de su corazón, medraba la devoción de los fieles hacia él» ${ }^{159}$.

El ya mencionado manual del inquisidor Bernard Gui, facilita información a propósito de otras herejías y sus relaciones con la mentira. Coetáneos y supervivientes al catarismo, los valdenses aparecen como contrarios a ella, puesto que todo hombre que miente, según la Escritura mata su alma ${ }^{160}$. En el caso de los apostólicos herederos de las predicaciones de Gerardo Segarelli, se establece un matiz: pueden mentir en caso de no soportar el poder de la inquisición siempre que ello pueda librarles del castigo, ya que se supone que, en su corazón, siguen siendo miembros del grupo. Si no pueden evitar la muerte, están obligados a confesar las verdades de su secta a fin de «morir en su seno con paciencia y constancia» ${ }^{161}$.

Ciertas simplificaciones elaboradas desde el lado católico contaban, sí, con el soporte de algunos testimonios que se han conservado redactados en el lado cátaro. Uno de los más relevantes es el que lleva el significativo título de Libro de los dos principios atribuido a Juan de Lugio y escrito en Lombardía en torno a 1240. El Dios malvado, «Señor y creador, según nuestros adversarios, consintió la mentira, enviando un espíritu malo y un espíritu de mentira; por lo demás, al espíritu de este Dios se le llama espíritu malvado y espíritu perverso, como está escrito en el primer Libro de los Reyes» incumpliendo las promesas hechas a Abraham y su descendencia ${ }^{162}$.

Usando en provecho propio el pasaje de una de las epístolas católicas, Juan de Lugio dirá que los cátaros (aunque él no los denomine así) son herederos de los antiguos profetas y apóstoles ya que, al igual que ellos, serían objeto de persecución por: «maestros embusteros que introducirán sectas de perdición y renegarán del Señor que los redimió, atrayendo sobre sí una rápida perdición. Y muchos seguirán su libertinaje y por su causa, el camino de la verdad será blasfemado». (2 Pe. 2, 1-3). La mentira y la blasfemia acaban siendo compañeras de viaje en la perversión de la lengua ${ }^{163}$. Tanto como la mentira y el juramento en falso ${ }^{164}$.

Los disidentes serán también duros en extremo a la hora de juzgar a la iglesia romana. De definidora y guardiana de la verdad, pasaría a ser la Roma «traidora y mentirosa» del poeta tolosano, filogibelino más que herético, Guillermo Figueira quien criticaba la política papal en relación con la cruzada cuya finalidad original parecía

\footnotetext{
158 Beato Jordán de Sajonia, op. cit, p. 158.

159 Pedro Ferrando, op. cit., p. 307.

${ }^{160}$ Bernard Gui, Manuel de l'inquisiteur. I, p. 61.

161 Ibid. pp. 93-95.

162 «El libro de los dos principios», en El legado secreto de los cátaros, Ed. de F. Zambon, Madrid, 1997 p. 106-107.

163 Ibid. p. 122-125.

164 Sobre esta última cuestión aplicada a diversas corrientes heréticas vid. A. Vauchez: «Le refus du serment chez les hérétiques médiévaux» en Le serment vol. II. Théories et devenir, Paris, 1991.
} 
sacrificarse en pro del enfrentamiento con el emperador Federico II. No se critica a la cruzada como tal; simplemente se lamenta la perversión de su espíritu frente al que se defiende la «verdadera cruzada» convertida en argumento de propaganda política ${ }^{165}$. Una anécdota posiblemente, pero con valor de categoría a pequeña escala cuyo espíritu veremos reiterado en los años siguientes.

b) La oposición a Roma: del declinar del Medievo a los orígenes del mundo moderno

Las corrientes críticas del Bajo Medievo volverían a insistir en su forma de entender la verdad a través del cuestionamiento de la iglesia oficial.

Roma era responsabilizada cada vez con mayor aspereza, de hacer descansar su poder sobre un cúmulo de falsedades. Marsilio de Padua había trabajado en esa dirección en múltiples pasajes de su Defensor Pacis. Y lo hará por los mismos años (hacia 13461347) otro de los grandes espíritus críticos del Medievo: Guillermo de Ockham ${ }^{166}$ quien, frente a los que sostenían abusivamente al papado aviñonense, negó que la plenitudo potestatis careciera de límite tanto en lo temporal como en lo espiritual ${ }^{167}$. Ello por no entrar a fondo en las críticas a otras dimensiones del poder temporal de los papas como la de Lorenzo Valla, al denunciar (1440) la (falsa) Donación de Constantino que servía de base para la legitimación del poder temporal de los Papas De forma tajante afirmará que «la Iglesia no ha de combatir más que contra el mal y sólo con armas espirituales» ${ }^{168}$.

En 1379 el maestro oxoniense Juan Wyclif, considerado entre los grandes intelectuales del Medievo ${ }^{169}$, escribió un Dialogus sive Speculum Ecclesiae militantis ajustado a unos esquemas típicamente escolásticos: la Verdad es identificada con la persona de Cristo, enfrentada a la Mentira que lo es con Satanás ${ }^{170}$. Algunos de sus puntos de vista -entre ellos la identificación de la Iglesia romana con una suerte de creación del Anticristo- fueron solemnemente anatematizados como heréticos en el concilio de Constanza en 1415 en donde, asimismo, fue condenado a la hoguera su seguidor el maestro checo Juan Hus ${ }^{171}$.

\footnotetext{
${ }^{165}$ Citado por C. Morrisson, Les croisades, Paris, 1973, p. 112s. Sobre la crítica a la cruzada por distintos motivos y desde fecha temprana vid. E. Siberry, Criticism of Crusading. 1095-1274, Oxford, 1985.

${ }^{166}$ Sobre este autor vid. M. Reuter, «Language, Lies and Human Action in William of Ockhams's. Treatment of Insolubles», en Vivarium 36 (1998) pp. 108-133.

167 Guillermo de Ockham, Sobre el poder de los emperadores y los papas. Ed. de J. C. Utrera. Madrid, 2007, pp. 65 ss. Una cuestión abordada con similar sentido crítico por el mismo autor en Sobre el gobierno tiránico del papa. Ed. de P. Rodríguez Santidrián. Madrid, 1992, pp. 26s.

${ }^{168}$ Lorenzo Valla, La donation de Constantin. Ed. de A. Bonneau. Paris, 1879, pp. 326s.

${ }^{169}$ A la altura de Pedro Abelardo, Santo Tomás de Aquino y Siger de Brabante. J. Le Goff, Los intelectuales en la Edad Media, Barcelona, 1986, p. 12.

${ }^{170}$ Reciente edición catalana de este texto a cargo de N. Figueras y M. Sitjar bajo el título L'espil de l'Esglesia Militant, Barcelona, 2001

${ }^{171}$ Algunos autores han considerado que más que discípulo o seguidor del oxoniense, el bohemio sería su defensor. G. Leff, «Wyclif and Hus: A Doctrinal Comparison», en Wyclif and his Time (Ed. de A. Kenny). Oxford, 1986, pp. 105ss. Para el lector español la obra de más fácil acceso dedicada al reformador centroeuropeo es la de J. Macek, La revolución husita. Orígenes, desarrollo, consecuencias, Madrid, 1975.
} 
Los más radicalizados de sus discípulos -los taboritas, teñidos de un marcado milenarismo- no se quedaron atrás a la hora de autodefinirse como poseedores de las «verdades salvadoras (que) se encuentran extendidas por toda la nación (bohemia) y al alcance de todo el mundo». El encarnizado enfrentamiento armado con los católicos no se podría apagar, concluían (1433), «mientras la santa verdad no sea respetada y fielmente admitida por todos los miembros de la Iglesia» ${ }^{172}$.

Algunas de estas quejas eran razonables tal y como hace unos años recogía un conocido historiador católico estudioso de la Alta Edad Moderna: «En general, a finales de la Edad Media podía preguntarse si la Iglesia, que había tenido dos o tres papas al mismo tiempo durante el Cisma de Occidente y que había quemado a personajes tan santos como Juan Hus, Juana de Arco y Savonarola, seguía manteniendo la Verdad. ¿Debían pasar necesariamente por esta institución pletórica y cansada el diálogo entre Dios y el hombre y la salvación de las almas?Estas preguntas estallaron en la época de la Reforma» ${ }^{173}$.

La expresión reforma está dotada de un amplio vuelo. Se ha aplicado por los historiadores de la Iglesia a todos aquellos movimientos con aspiraciones renovadoras que jalonaron el Medievo. Especialmente, a partir del gregorianismo más oficial - que, dentro de las normas establecidas, trató de mejorar las costumbres del clero y de lograr la independencia de la Iglesia en relación a los poderes políticos ${ }^{174}$ - hasta desembocar en corrientes que como el Wyclifismo y el husismo, chocaron abiertamente con el orden establecido ${ }^{175}$.

Las familias reformadoras del Quinientos (ya fueran o no condenadas como heréticas) constituyeron en parte movimientos epigonales de las inquietudes religiosas del Bajo Medievo ${ }^{176}$. Hace casi un siglo, uno de los grandes impulsores de la sociología moderna y profesor de la facultad de teología de Heidelberg -Ernst Troeltschsostuvo que el protestantismo «considerado desde el punto de vista de la historia ecle-

\footnotetext{
172 «Discurso de Procopio el Grande a los enviados del concilio de Basilea sobre las esencias de la guerra de los husitas (junio, 1483)», recogido por J. Macek, ¿Herejía o revolución? El movimiento husita, Madrid,1967 pp. 123s.

173 J. Delumeau, La Reforma. Barcelona, 1973, p. 20.

174 Para una valoración global de la llamada reforma gregoriana, vid. entre otros títulos, el venerable de A. Fliche, La réforme grégorienne. 2 vols. Lovaina -Paris, 1924-1945. y los mas recientes de J. Paul, La Iglesia y la cultura. pp. 309ss. y O. Capitani, L'Italia medievale nei secoli di trapasso. La Riforma della Chiesa (10121122), Bologna, 1984. Sobre las diferentes formas de entender en el Medievo (y, sobre todo, de cara al Medievo) la expresión reforma, vid. el apunte de E. Mitre, «El concepto de reforma y el mundo medieval (Realidad histórica y categoría historiográfica)» en XX. Siglos, 34. (1997), pp. 21-28. Recogido en Fronterizos de Clío. (Marginados, disidentes y desplazados en la Edad Media). Universidad de Granada, 2003, pp. 121-137.

175 Un clásico para estos siglos finales de la Edad Media lo constituye la síntesis de Gordon Leff, Heresy in the later Middle Ages, Manchester, 1967. Una visión panorámica en E. Mitre, «Disidencia religiosa en el Bajo Medievo ¿Una forma de contestación social?», en Edad Media. Revista de Historia 4 (2001) pp. 37-58.

176 Para el establecimiento de ese continuum vid. P. Chaunu, Le temps des reformes. La crise de la chrétienté. L'éclatement 1250-1550, Paris, 1975; o S. Ozment, The Age of Reform . 1350-1550. Yale,1980. Desde la óptica del medievalista vid. F. Rapp, La Iglesia y la vida religiosa en Occidente a fines de la Edad Media, Barcelona, 1973. Sobre los precedentes ideológicos del luteranismo que hincan sus raíces en el Medievo es de interés el ensayo de R. García Villoslada, Raíces históricas del luteranismo, Madrid, 1969.
} 
siástica y dogmática no es más que una transformación del catolicismo, una prolongación de planteamientos católicos a los que se ofrece una nueva respuesta» ${ }^{177}$.

Los grandes protagonistas de las rupturas en los inicios de la Modernidad agudizaron las críticas de siglos atrás contra la Iglesia romana. Martín Lutero, por ejemplo, se declaró un instintivo seguidor del husismo a través de una conocida sentencia pronunciada en 1520: «Todos somos husitas sin saberlo» ${ }^{178}$. En una de sus primeras manifestaciones de abierta animadversión hacia la sede apostólica invocaría la tesis paulina del sacerdocio universal por la que todos los cristianos «son de la clase sacerdotal y no hay entre ellos diferencias, a no ser a causa de su oficio. Todos juntos somos un cuerpo, del cual cada miembro tiene su propia obra, con la que sirve a los demás» (1 Cor. 12, 12). El papado es acusado así de ostentar un poder basado en «una mentira sutil y una hipocresía». Una forma de reprobar la radical división entre la «clase sacerdotal» de obispos, sacerdotes y conventuales, y la «clase mundana» compuesta de príncipes, señores, artesanos y campesinos ${ }^{179}$. Denunciaba así Lutero a Roma como sistemática y estructural transgresora de la verdad; una actitud que arteramente habría ido sosteniendo a lo largo de los siglos.

Tan duro como Lutero a propósito de los abusos del Pontificado lo será otro reformador que acabó entrando en colisión con el: Erasmo de Rotterdam. Su más áspero alegato será posiblemente el diálogo mantenido por San Pedro y el papa Julio II. Texto que, por prudencia, el roterodamo no publicó pero que acabó siendo editado sin su permiso. En él presenta a un Julio a quien se le impide el acceso al reino de los cielos a causa de sus graves pecados, numerosas trapacerías y el cinismo con el que defiende su comportamiento mundano encaminado al engrandecimiento puramente material de la Santa Sede. Frente a la idea de Pedro que define la Iglesia como «el pueblo cristiano aglutinado con el espíritu de Cristo», el pontífice la presenta como «los templos sagrados, los sacerdotes, y especialmente la curia romana y en primer lugar yo, que soy la cabeza de la Iglesia ${ }^{180}$.

\section{CONCLUSIONES}

Los cotidianos enfrentamientos entre verdades y mentiras que jalonaban la vida humana constituían parte relevante de ese combate espiritual en el que se desenvolvía el cristiano en su tránsito por este mundo. ${ }^{181}$ Eran, asimismo, reflejo de bajo vuelo de

177 E. Troeltsch, El protestantismo y el mundo moderno, México, 1967 (original en alemán publicado en 1911) p. 38. Tiempo atrás y desde la Ilustración alemana, G. E. Lessing abogaría por una búsqueda de la verdad más que por su posesión. Cf. en Ibid. p. 104.

${ }^{178}$ Recogida por J. Macek, La revolución husita, p. 262.

179 Martín Lutero, A la nobleza cristiana de la nación alemana, sobre el mejoramiento del estado de los cristianos. Ed. de M. O. de Bopp. México, 1977, p. 17. Especie de introito a un largo memorial de agravios que, se afirmaba, los alemanes en general tenían contra el papado.

${ }^{180}$ Erasmo de Rotterdam, «Julio II excluido del reino de los cielos», recogido en Escritos de crítica religiosa y politica, Ed. de M. A. Granada. Madrid, 2008, p. 55.

${ }^{181}$ Un extendido subgénero de la pastoral católica será, precisamente el combate entre virtudes y vicios. Una guía-repertorio sobre este tema en R. Newhauser, The Treatise on Vices and Virtues in latin and the Vernacular, 
otra psicomaquia superior: la que oponía la Verdad y la Mentira ${ }^{182}$; con inicial mayúscula en ambos casos. De acuerdo a esa lógica inquisitorial a la que nos hemos referido en pasaje anterior, «acerca de la verdad divina no debe creerse más que a los obispos, a los predicadores y a los menores $\rangle^{183}$.

Como categorías supremas la Verdad y, a su modo también, la Mentira eran identificadas, respectivamente, con la vía recta y el error. Desde el lado católico era tanto como enfrentar ortodoxia y herejía. La visionaria alemana Hildegarda de Bingen, una de las grandes figuras de la espiritualidad medieval europea, hablaría a mediados del siglo XII de «la seca hojarasca de la divergencia, la rebeldía y el oprobio, adversaria de la recta fe católica» ${ }^{184}$.

Este discurso, en sus líneas generales, sería aplicable también a otra confrontación: la que se da en el Medievo entre cristianos y musulmanes. Lo veremos, por ejemplo a fines del Medievo en la controvertida misiva del papa Pío II (Eneas Silvio Piccolomini en el mundo) al sultán Mahomet II que constituía todo un compendio de las actitudes de Roma hacia «el otro» religioso. Con prolijos argumentos se le exhortaba a recibir «la verdad», a buscar «lo verdadero», identificado con «la fe de Jesús Nuestro Señor» ${ }^{185}$. Incluso, utilizando la munición ideológica de más grueso calibre, acusaría a Mahoma de haber mezclado, para engañar más fácilmente a los potenciales seguidores, cosas buenas y malas al igual que los herejes ${ }^{186}$. No en balde, Pio II echaría mano de un viejo argumento de los polemistas cristianos: la identificación del Islam con una mezcla de herejías cristianas que habían provocado una total tergiversación de la Verdad ${ }^{187}$.

Extramuros de los dictados de Roma, pero proclamándose siempre dentro de la comunidad cristiana, quienes cuestionaban la autoridad pontificia en sus más crudos

en Typologie des sources du Moyen Âge occidental 68, Tournhout, Brepols, 1993. Entre los textos de más relieve estará el del dominico Guillermo Peraldo,: Summa virtutum ac vitiorum. Ed. de A. E J. Britannicis de Pallazolo., Brescia, 1494. Ramón Llull presentaría la vida del caballero como una continua batalla entre los vicios capitales y las virtudes (capitales, teologales y cardinales) Libro de la orden de caballería. Ed. de L. A. de Cuenca. Madrid, 1986 pp. 75 y ss. Dos siglos después, Erasmo de Rotterdam, en su línea eminentemente irenista solo consideraba dignas las guerras contra los vicios. Esas eran las que debía emprender el caballero, cuyas armas primordiales serían la oración y la ciencia, Enquiridion. Manual del caballero cristiano. Ed. P. Rodríguez Santidrián. Madrid, 1995, p. 68.

${ }^{182} \mathrm{El}$ autor de la órbita intelectual soviética A. Gurievich recordó, aunque por otros motivos, que para los intelectuales del Medievo, «el mundo visible se hallaba en armonía con su arquetipo, con el mundo de las esencias superiores (Archetypus mundus)», en Las categorías de la cultura medieval, Madrid, 1990, p. 82.

183 «Tercera denuncia al obispo de Gerona», en Escritos condenados por la Inquisición de Arnaldo de Vilanova p. 109.

${ }^{184}$ Hildegarda de Bingen, Scivias: conoce los caminos. Ed. de A. Castro Zafra y M. Castro. Madrid,1999, p. 373.

${ }^{185}$ Eneas Silvio Piccolomini, Epistola a Mehmet II. Ed. de D. F. Sanz. Madrid 2003, p.55. Las especulaciones sobre este documento incluyen dudas sobre su remisión al sultán; lo que haría del texto un simple ejercicio literario-doctrinal. A favor de ese envío se ha pronunciado recientemente B. Weber, «Conversión, croisade et oecuménisme à la fin du Moyen âge: Encore sur la lettre de Pie II à Mehmed II» en Crusade 7, (2008) pp. 181-198.

${ }^{186}$ Eneas Silvio Piccolomini, Epistola a Mehmet, p. 167.

${ }^{187}$ Algunas cuestiones de este tipo las tratamos en E. Mitre, Los credos medievales y el espejo de la herejía. Madrid, 2006, pp. 58ss. 
pronunciamientos teocráticos, no seguían una mecánica muy diferente. Al igual que los católicos más firmes estaban también plenamente convencidos de la corrección de su proceder -rectitudo en la acepción más común- y de su consiguiente servicio a la Verdad $^{188}$.

Después de todo, como recordó en su día un distinguido teólogo que recorrió el camino del protestantismo al catolicismo: las herejías «suelen reposar sobre una percepción de ciertas verdades o aspectos de la verdad que demasiadas veces han sido desatendidas por muchos cristianos y hasta por hombres investidos de responsabilidad eclesiástica. Por lo común el hereje sólo llega a serlo cuando su entusiasmo por la verdad que ha reconocido le lleva a despreciar otras verdades no menos esenciales para la integridad de la fe». La solución al problema había de estar en reintegrar «a la unidad católica a los cristianos de buena fe que habían podido engañarse durante un tiempo sin culpa personal por su parte» ${ }^{189}$.

Y desde una línea conciliar semejante, en las que se lamenta el enfrentamiento secular entre ortodoxia y heterodoxia, se ha defendido un «ecumenismo» de la verdad que «aunque pueda ser un riesgo, es, sobre todo, una oportunidad de enriquecimiento para iglesias hasta ahora opuestas ${ }^{190}$.

\footnotetext{
188 Sobre la similitud de las actitudes éticas de ortodoxos y heréticos recogemos un apunte (a desarrollar en una amplia monografía) en E. Mitre, «Los pecados desde la herejía: la moral del otro en la Edad Media». En Pecar en la Edad Media. (I. Seminario Multidisciplinar. Departamento de Historia Medieval. Facultad de Geografía e Historia. Universidad Complutense. 12-14 de marzo de 2007). Madrid, 2008, pp. 281-296.

189 L. Bouyer: Voz «Herejía» en Diccionario de teología. Barcelona 1977, pp. 313-314. En la voz «Fidelidad» se desarrolla la idea de «fidelidad de Dios» (derivación del término emeth) como una noción fundamental de la Escritura. Ibid. pp. 283. Cf. Lo recogido en el pasaje apoyado en n. 5.

190 J. Moingt, «Oportet et haereses esse» en Concilium 212 (Ortodoxia y heterodoxia) ( 1987) pp. 88-89. Se recuerda a su vez como el vocablo haereses se tiende hoy en día a interpretar como bandos o partidos, lo cual le privaría del carácter enigmático y provocativo que a primera vista pudiera tener. Ibid, p. 81 .
} 